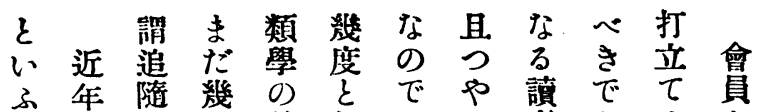
以の它前無あす者

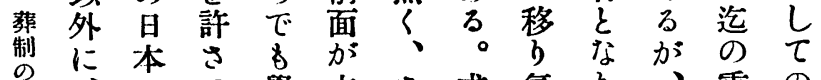
沿、0) 82 學本 $a$ 求氣 $b$ 、重 革此人を問來うめ汉々要我 に學類い正はいて見はれ論名 間 學ふ心弘ふ此充普に文の

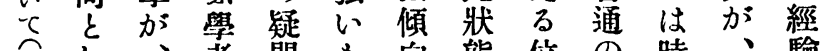
楖 ᄂ 、者問す向態位の時、驗 烈悲のがのを豫期連か は常深あで是招、約 も續ら 特に入

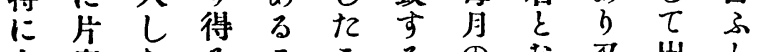

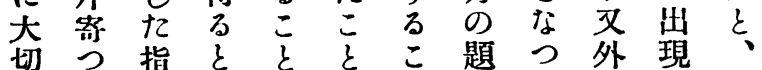

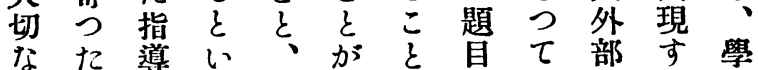
なた

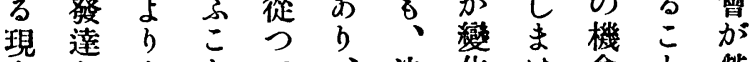

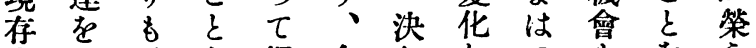
事し、在偶今 象た 全、然か $\tau \tau こ$ 件意る

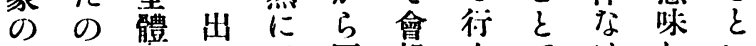

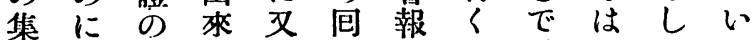

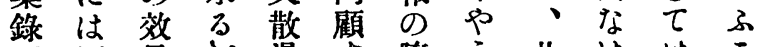
加原果だ漫す䧺う业けはこ 、因はけにる落な同れ居々

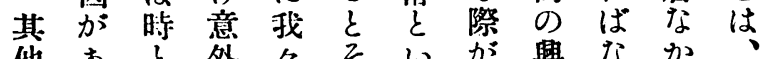

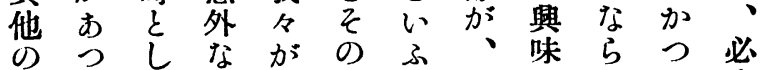

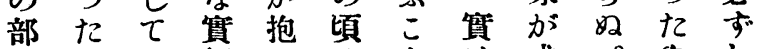
分。大例いの沙或。やし に或きにて方は次一今名 於 D 加居出出の掘少で精 て局つつ會來進にしあ透 は面たて 個員な出倾くるの

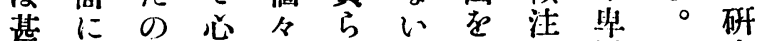
た優で付のし。焣せ近理究 无振秀あか小心現儿ずな想在

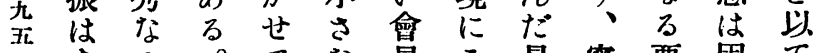

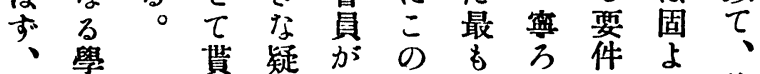
葬 制 の 沿 革

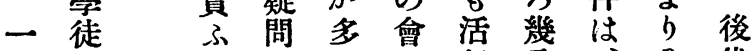

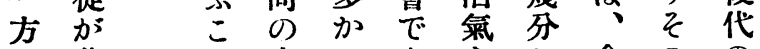

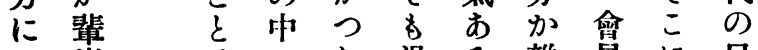

は出はにた過る雜貝に目 探し过。齿時駁各在標 險た所、人に代无單る寺 
か 前 來 $\tau$ 類 目

と者り無はせ 最

思にが心 数ら初

れこある多れに

るをつ市 いて 私

新 $\tau$ 加 8 居

其故、多のる 葬

中な全い。゙に制

探何之る拘沿

凶用處の 加ら革

事模に理、吉な

に倣行 由-、

ははつの榡日步

計あて主に本考

畫れるな任にへ

が、略る民比て

な俴同ものま見

く式じの生だよ

にるは活明う

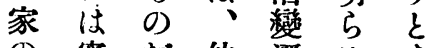

の 票だ他邆め す

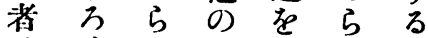

は改う俗詰れの

通正々 信吉ざは

其機了呪衣不通

指 會 豫 法

揮 が 断 の 疎 方何

に少が類で 幾れ

任な お と あつ の

しくるはるを 民

得、こ正と方族

な從を原心るで

いつで 對 ふ か ह

かてはに中 ら是

ら土無、にで が

地 心是 管 お 最

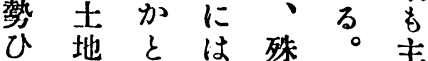

们 の 思たに近要

人背ふぶ此年な

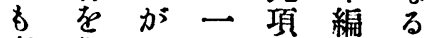

责保、つ目述文

任存算のにせ化

老際定はら施

負易は支力れ-

jか却つ质特

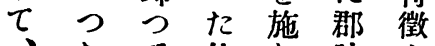

題好々 來㫞 ひ か ら 弥 目記をははにう掘 に念差發稍相た等 興の控見お 迹の し 味日へ加くけは专菲

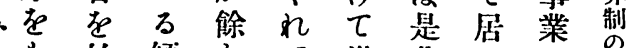
始傾り隻非るす

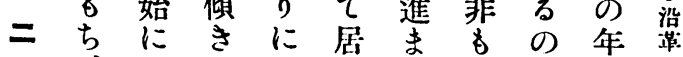
、しが少るな無でをに

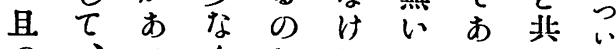

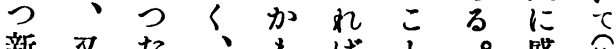
新又た、视文。盛柳 ら僅加又知!で人九思 しか、た占末、間な いつ是まぬに計生る 資 す 之閣く あ 今 角 る 觀主 制題なつかの公 測て な $心 \tau \zeta$ 所け と b 流子古謂の学こ をと行其当史調の市 以をに發ま前查直方 て提が見だ學が接で 出ぶが何の 今

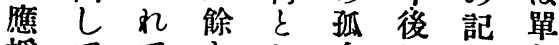

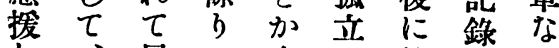
乙居に方学於它る $\tau$ 同た小法へて好

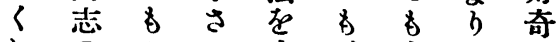
れの 小立、倘他心 ら會だの学望にの れ貝とにる細みは地 乃諸 $心$ 恥必く幙、表 か君ふ ぢ 要なく何探

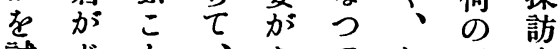

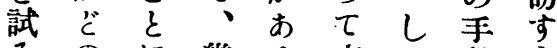
みのに幾る來加段ら 七 程究分 見度付少うで各哭、 よに心局にあ部い段䒕 j、た 思ら各學名充 思如今 先方。 こ年問に s何度進自文 9 、行 な の分を考成抽 る五比な考察長く 種百へをへ方しれ 類號るるる る得と 


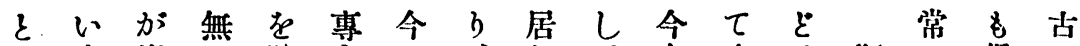
思光出以踏ら日操い

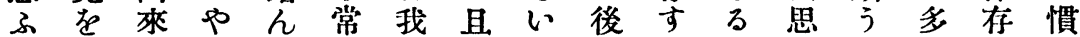

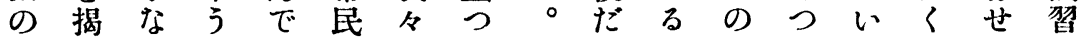

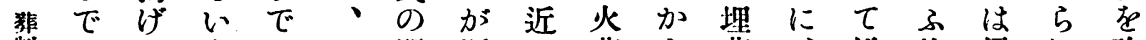

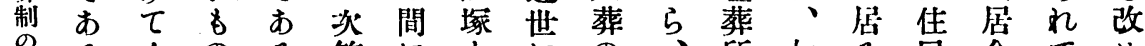
沿るくの る 第に $に$ に 龩。かか。に行い入方人は何。のは居よ

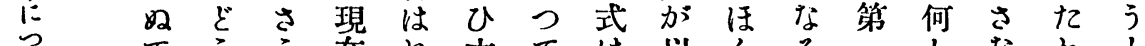
いでうう在れ古て は以んる -c

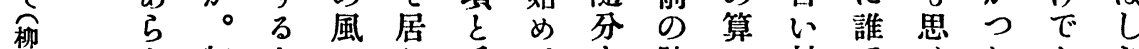
开 j 郎 $と$ に呼て $て$ 跡へ村ではたなな かち 現移こぶ探古をるにるずのるか 。民在つを各用く忘程す不にでがつ

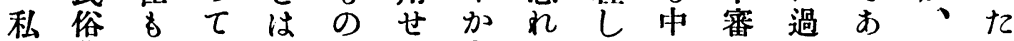

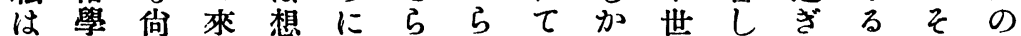
この行た像由れ、しな 以てで の今はかしつた行まい前よ居まる

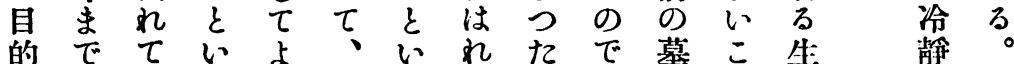
を他居ふ心類了た加 お場方活郎 以の る こ の 推筫 や

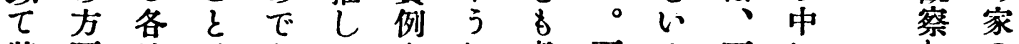

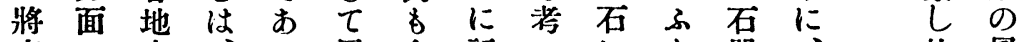
來に方、る。居多記 の 地

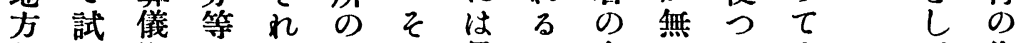

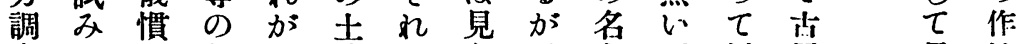
查て 珀知如葬で充、蛋。居風 の居のる 何以居等ま刻生た可 篇た中限な外宁だすれ時尋

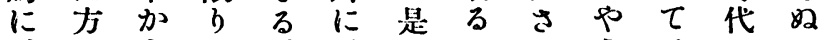
、法らに樣、はがううはのへ 特は、於式别 に、或てのに迄勿及なん骨当 二何ははすーに論場つだでの

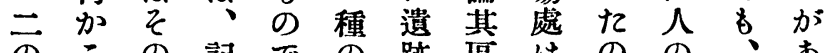
䒕 項 の

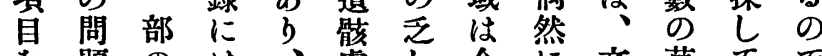
を題のは、處し令に交莫てで 提に消是棸理いでお字大居は 出對息 $\varepsilon$ 法の發方なる 無 ししをいう加を 限見一の $\tau \tau$ 賽ふいあ見らせ通に追か

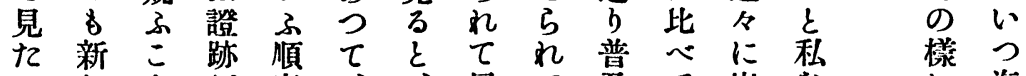

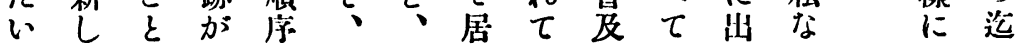




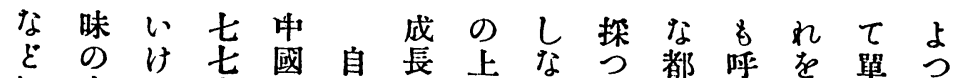

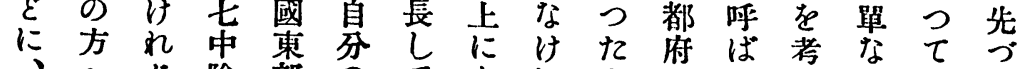

人

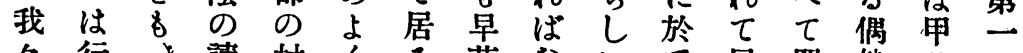

々行、諘村くる著ないて 居置然乙 に

のか多經な 知。しらが薄然何注

蓦な 分ま

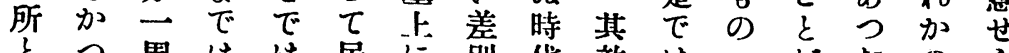

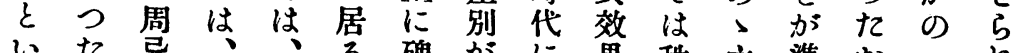

いた忌、、る碑加に果秩主準か一れ

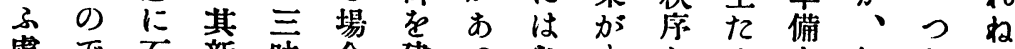

處で石新昧合建つなま㠿ると但しば

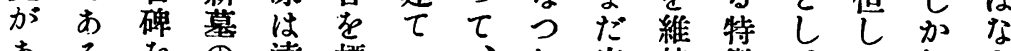

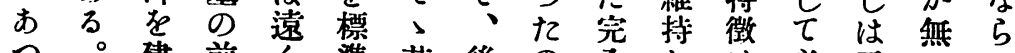

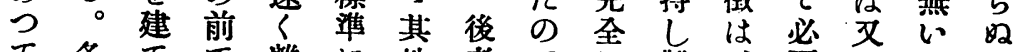

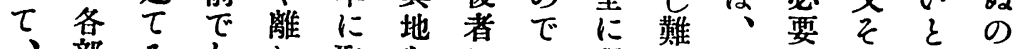

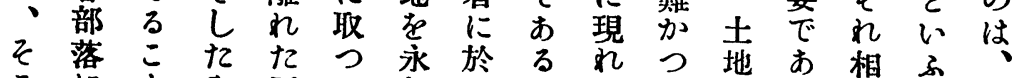

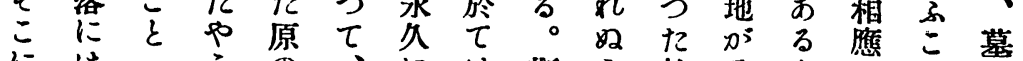

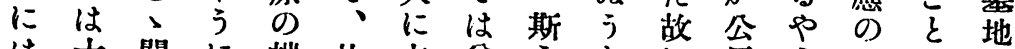

は十關に端此占睤うちに角う原でに 小古聯思に較有元いに、公に因 な 三 し ふ。

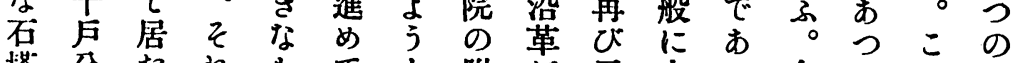

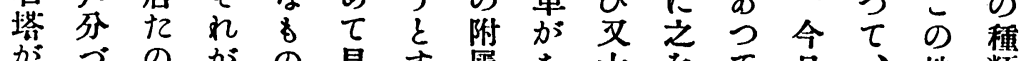

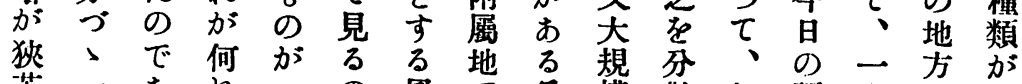

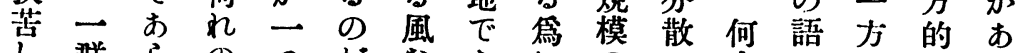
し 群ら

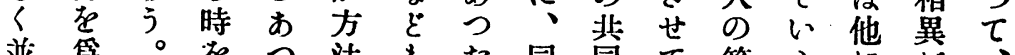

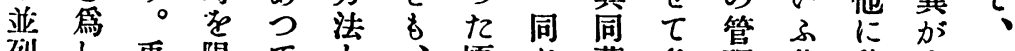
列し 鬼限它它頃し墓各理其移多飞

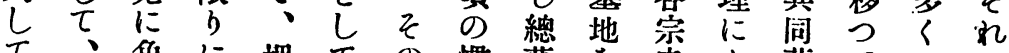

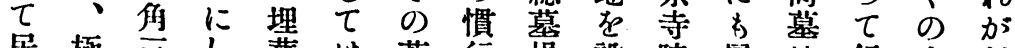
居極年し葬は著行場設院屬地行人 村 た年た の 最し がで定のしいに 盆 民

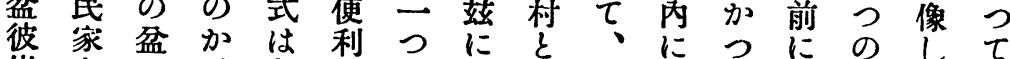

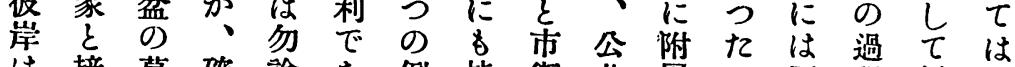

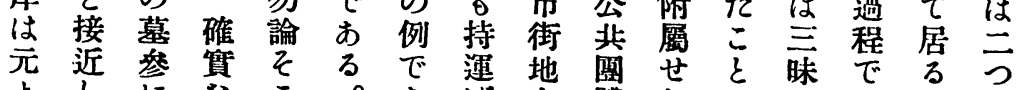

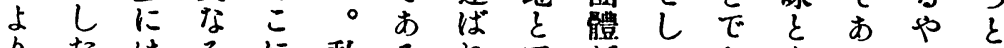

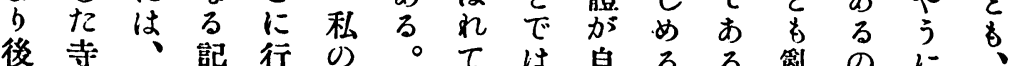

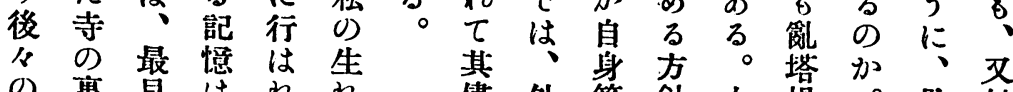
の襄早はれれ儘外管針大場。果村

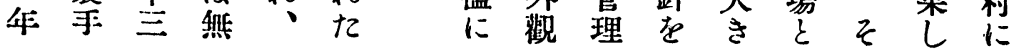




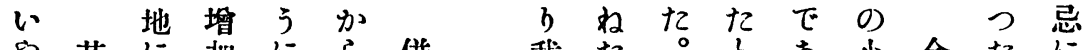

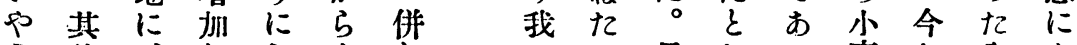

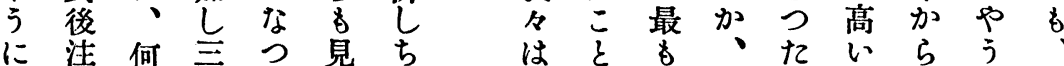

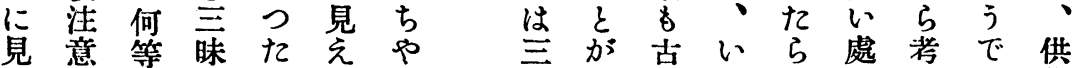

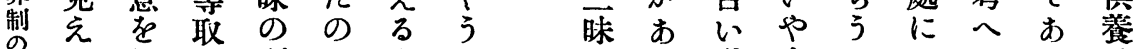
沿るし报利でや艺居る私今 か 革處七上用 にも見の加るに頃四だ其記しいのるる

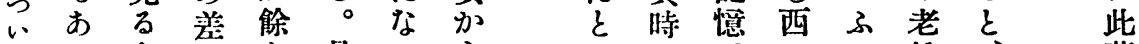

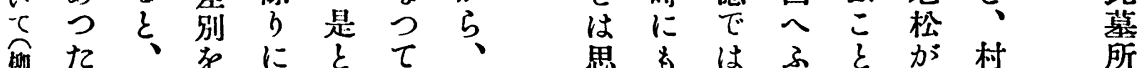

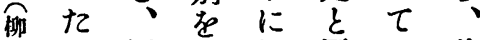
四。同設 繁同來此 併しけく時た督 し中ななに。同 飞國少了部移慕

このつて 落佳地

に田た、に者に は舍結新近や多 必で果蕉 心新片 ずす での 寺胳 中、お草内离に 央土るくや分三 に地。邻森家つ 浆に澱の 三 同よれな墓う

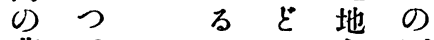
葬てこにを石

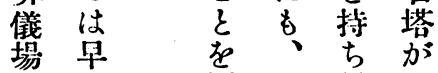
方く 厭 次得立 あ か ふ 第な ち り 占少に心始 其云種 占 人 者市

周 0)、㓐、居

固墓つ埋た

に地まる葬。 はが bこ所を 一多連はと学れ 旮 $人$ 接 法に其 か のし制な 儘追

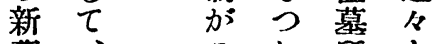

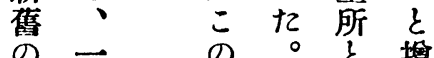
㧘見 二 是

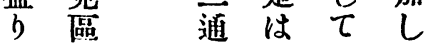
土別 b家拜元

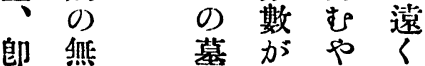
つ松、つであ民币

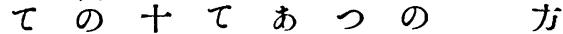
居 樹 年 店つた幕 だ なのほたたにに の

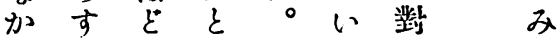
つぐ前がつ香

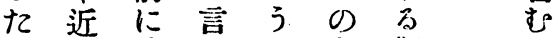
の 此つす 蕉觀 でで 野 $て る$ 式 念 あお浐、とのは に るつに大每日、 た邆よにに確尗

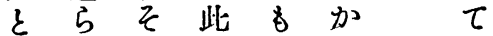
いれあ松必に后 ふたの の吉現 の自 あ樹會代

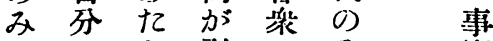

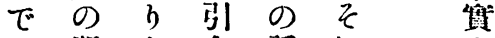
、沮飞合話れ 確 捍: $ひ$ 頭 $\varepsilon$ 品分にに珙 に、以出上な

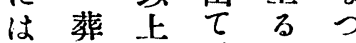
何處に、のて 人は、是は居

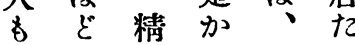
敎れ密ら誰 へたに南々

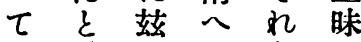
く言た 三をの

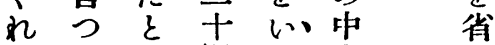
な咅間け、决み か 親 ふ 位 た、によ $つ$ し 者 0 の 近 た心は處はく 。者 無 で ど、 $つ に$ あ $の$ 路 ま娑つつ邊胎 径 葬 地 は 何 人 8 之 み $\sum_{j}^{k}$ ह 沓 


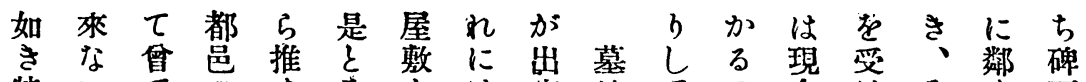

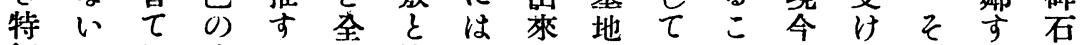

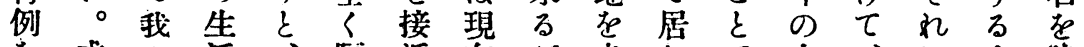
を或々活、隔近在が寺たで士、に士建覑

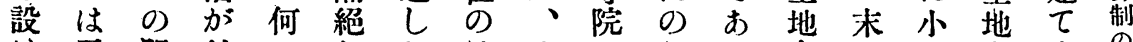
け文間始かした地飞にだ名名にさすすす沿 记新にま特た控方の托か。寄はな卧に范 かた、つ别南へ資一卞ら要帳寺庵九自に のに一ての旮地料つる後卞な號室だ然い

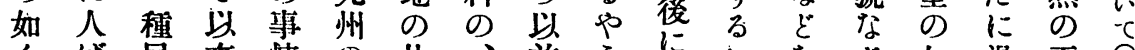

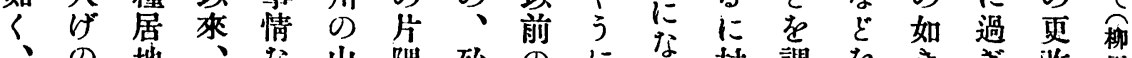

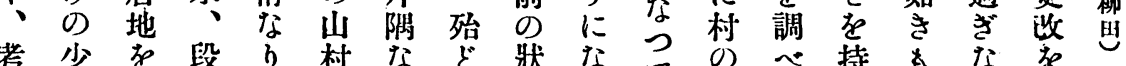
考少存段占村な

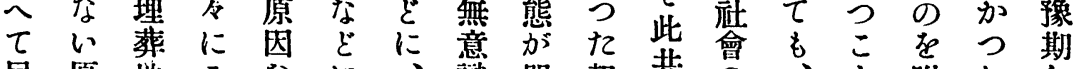
居原地こなに、識明起共の同它附てし

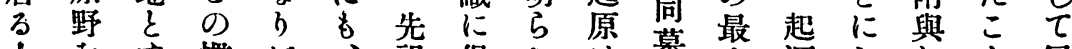

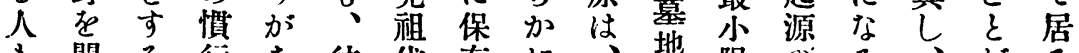

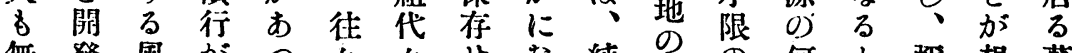

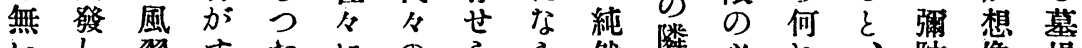

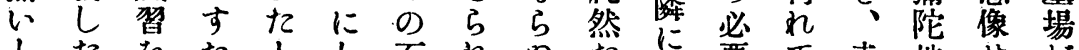

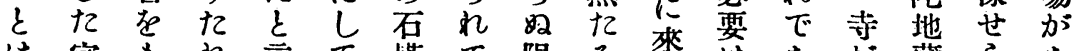
は家もれ言て 塔て 限る來 は

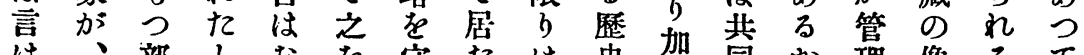

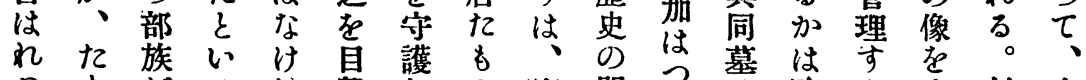

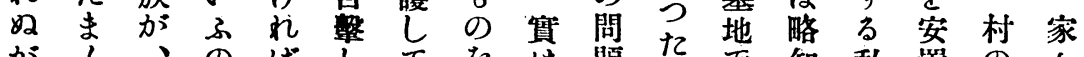

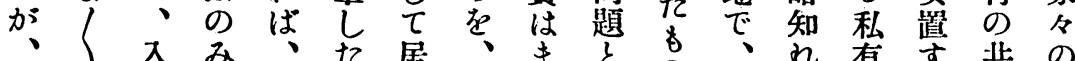

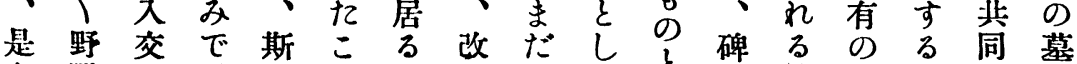

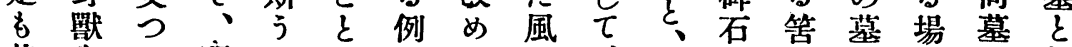
其 墓 外在 現

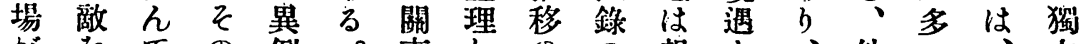

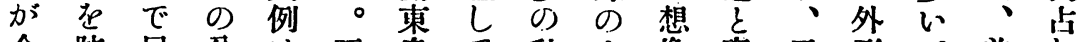

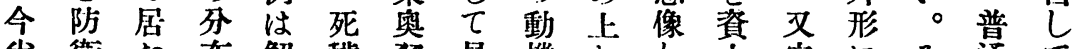

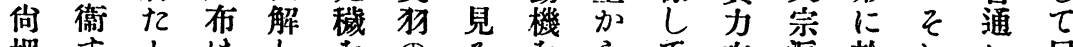
埋すをはし を

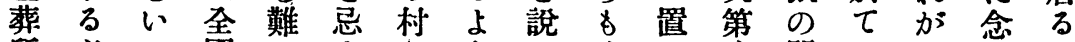

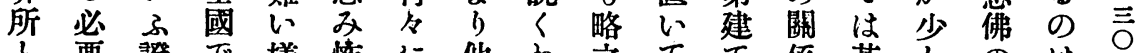

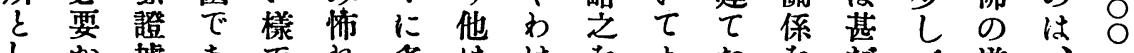

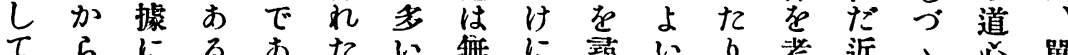
て、、に る

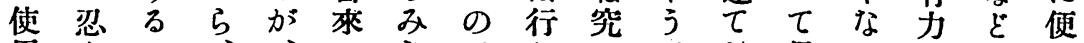
用んこ、、のなでかあでな見る者を宜

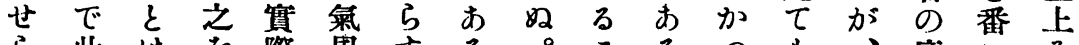

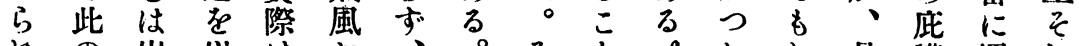

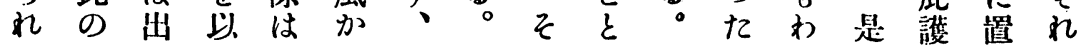


ての此るでは片岕來で

居村或傻の市、方林るす墓 てなはにをる何のでや謂地 が ぞ る見。れ松あうはに 倠、で樹三た其す林るになは 制よb宁 の 昧。後人方例思け斯

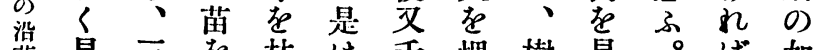

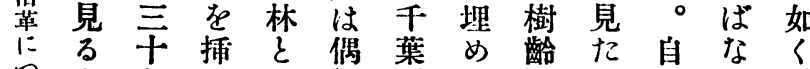
o

一砂前代る汇長土馀謂のなる

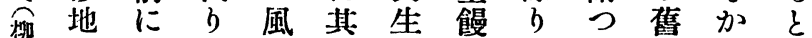
想に息に㕷間郡頭にて友つ云 罯分、がにので不居のたつ

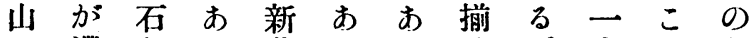
の滞をる墓るつひ。人を種 海在置こ加淋たで自はは類

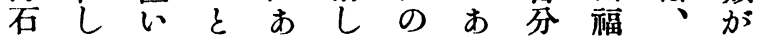

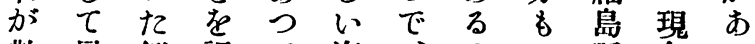
散居 例認 $\tau$ 海、の三縣在つ

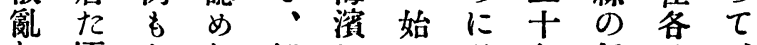

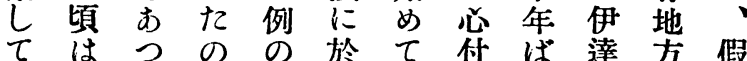
居、たで犬て此いか郡のに

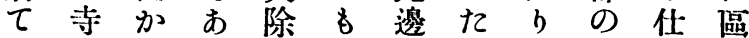

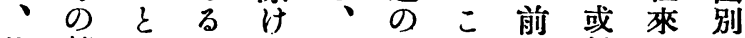

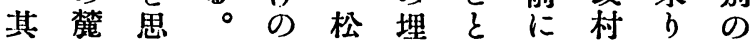
一に つま。在 6 法

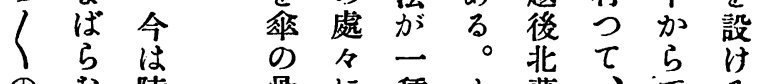
のな陸骨に種よ蒲、でる 在松軍 b 林 處加砲 が あ 術

葬 つ 練 地 $\tau$ 㕷 で、地 あ 常に

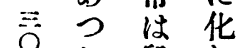

- 致兒

石童望

碑 遊 河

は吹の

松場 伊

林良

のな 湖

片亏 岬

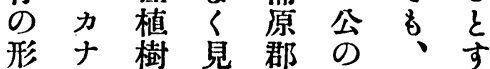

にメのるの交可れ

刺 ・風占海書なば

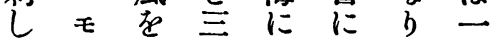

霞于伴年近は明方

う,な五心墓瞭蛋

乙 $\neq$ 年㲘地に葬 るの居若をお老 の 瀾る 松通 つ䨘他

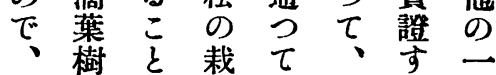
い加点居其る方 と栽知宁實こ农 容总亏 あ、立察 易元た路派加地 にあの下のな出 居 等 $\tau$ の 道 $を$ 之地
乙菁定 $\tau$ \% の 居 直道る ら 接はの に別他 はにはの 之其 無 が 五立前 關少。い 係 5 郎 0 加具 5 t 無は我見 かつ斿 つてはば 七居威、 b た し。佛は い⿹ 法 b の $引 0$ 亦 でし 数 成 क $\tau$ 化 咅 万今 にた あ 信 ざ る賴る 如 L ₹ 野、の 邊亡 想 揆魂像 乃 の で の 管 あ 儀 理 つ 式素标 塊由 葬 委來 地ね 考不 直 引 明 万反 に ᄂ ह 墓们の 守けは ろ 風名は は 固 所有 必㯰 


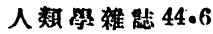

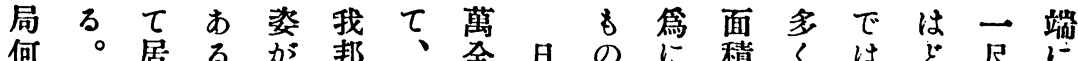

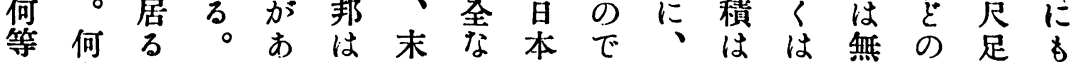
加古如古る 繁にるに無文何手心位ら少

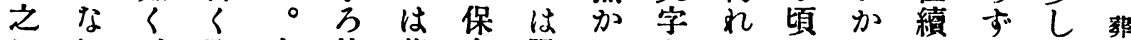
にれ、湖寺特著存限つを尼の㓝

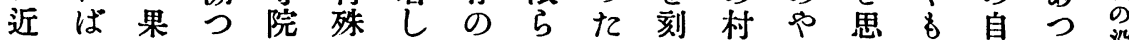

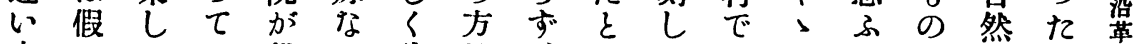

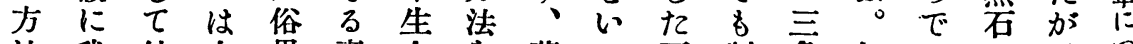

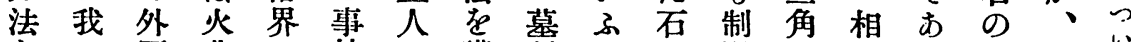
名國葬 の情 の請制こ塔限形州つ多艺

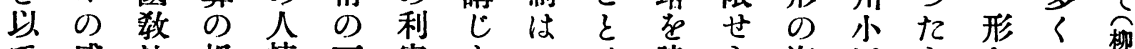

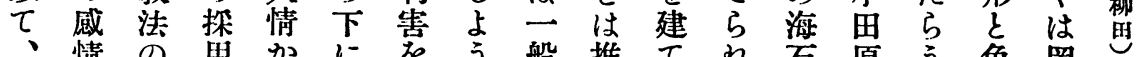

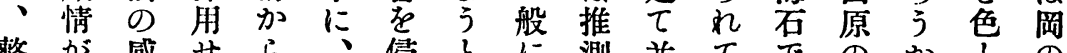

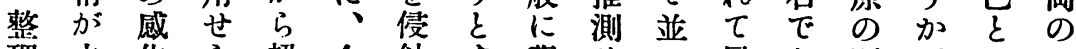

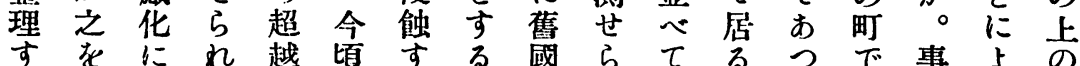

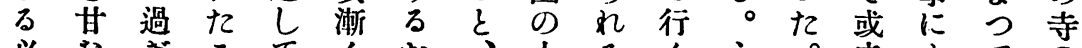

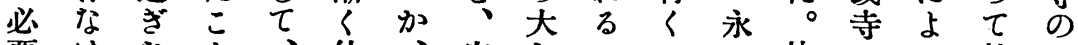

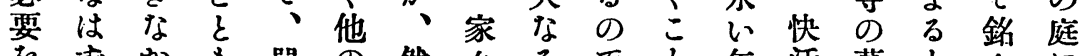

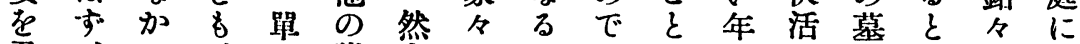

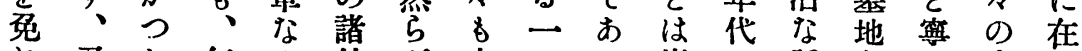

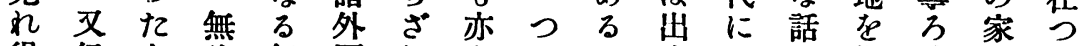

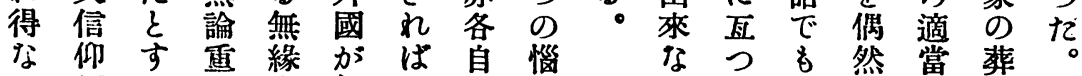
が的要有解稍 のみ つ誘ばな緣決慘能で た導、る尼世酷力お かし 其一標んなのう

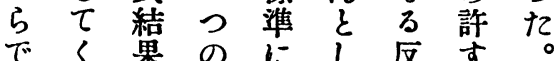

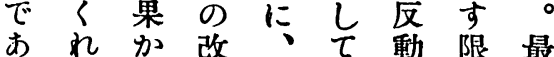
るなら革多居行引初 ・見でくる篇、に つ $て$ の 問 を次は た殊 つ慕題忽第富

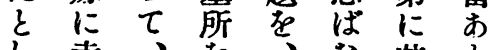
し 幸、存、な其 b $\tau$ 福々整幾け風檴 もなれ理分れを勢 莫偶在得早ば傳 墓偶在得早な苗方 地然來舜貝 大心歷と解 のは、 のふ史は決で自地 傾 乞家其し 向きの二たる占 はで認つかがあめ 結あめで 加䒜にな地 但

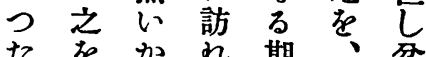
笘使ら简間見 で用人この分は しは主後け雙 從よ隇方にる方 うう多あ、のに $\tau$ 子につ忘だ於 現 寸 斯 $れ$ れ $\tau$ 在 引 のばい、しの老

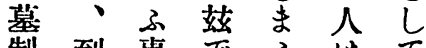
制到事でふは艺 の底唡 こ言居

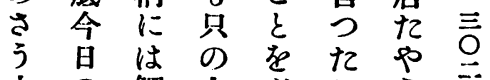
古の觸人必宓方 く樣れの要、に かに心慕

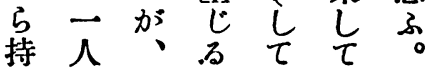
續墓し居其大 し夕地はた記き たのの、の憶さ 
蕜な敍る增仰 人斯所あ寺死於で くるへ。加自、らう謂つ院にであ然

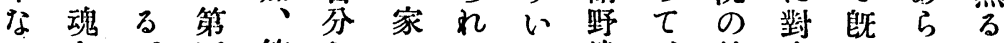

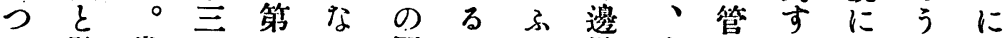

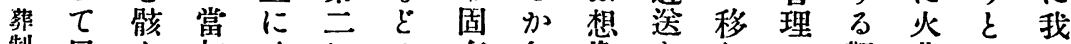

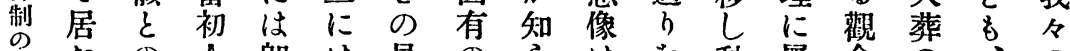

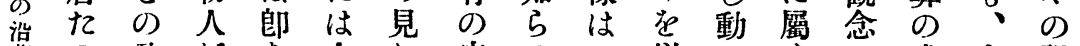

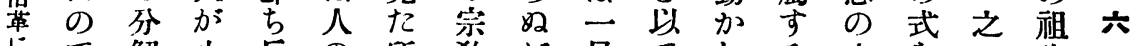
にで解少戸の 所敎が見てしる中をに先 ○あ方なの 威で基の

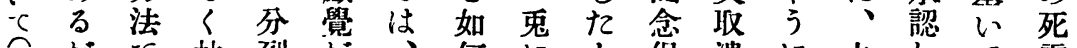

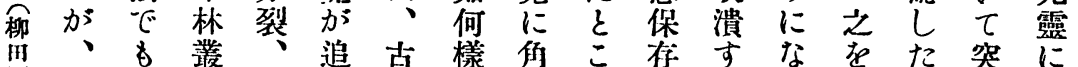

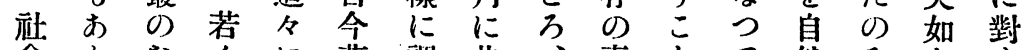

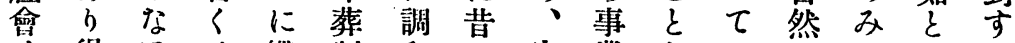
は得䚾は纎制和の家業をがのなし る

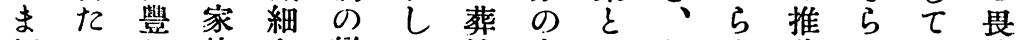

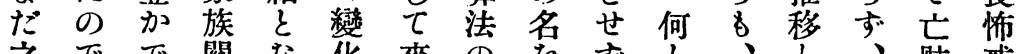
之でで關な化來の委ずと、文䯓戒

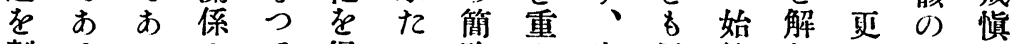
劃る。只 的邑時等所へ认侁二浩る 代方今

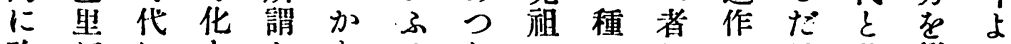

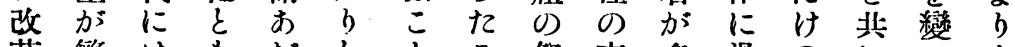

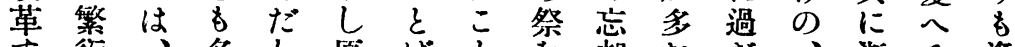
专衍、名し原ば 万し才く野因加大方了た若次こか

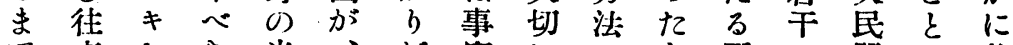

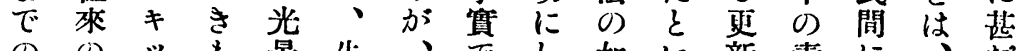
ののッも景少、无し如い新素に、た

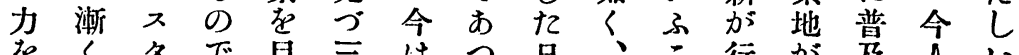

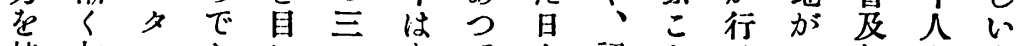
持加

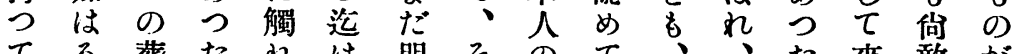

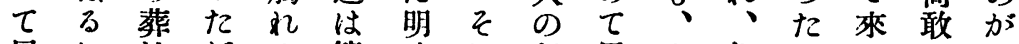

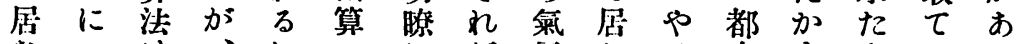
なつは、にへにか風たは府らをせ

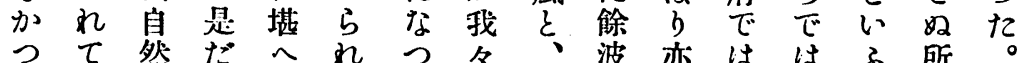

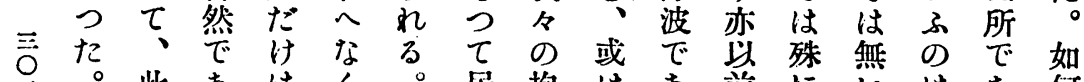
三。此 あ はく 閴雀 つ

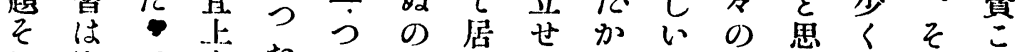

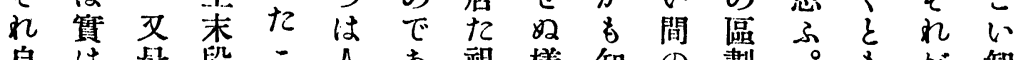

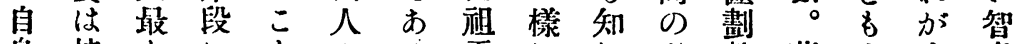

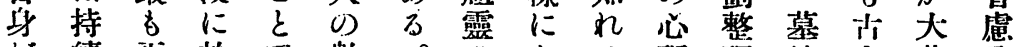

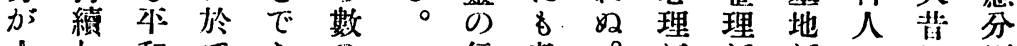

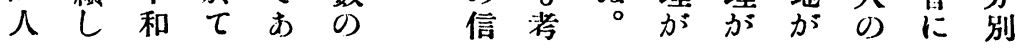


ふ考國起て味

地 $に b$ に

名ら幾に, てカ

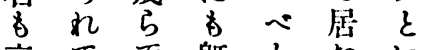

京て で既々たた

都居すに謂か子

のた例点つ $っ$ 日

そ 加地西本

れれ る 居ふ語

の $匚$ る

みるか子人、本

が、ら意加確來

著語、味多加漢

名の 是 が いな字

で元はあ。この

あの少つ鳥意墓

が味くの野また

、はとか鳥だは

古境 櫋自相

间或 京知山分當

にこ都れ知にせ

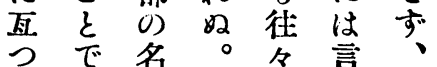

七、寻現にへ管

其 即移在しなろ

數 $t$ 西 $\tau$ 小斯

加㙄机院之。う

非をの川兔い

常解で原普にふ

にしはの通角菖

多た無四名に吕

い人い学詞々ら

中

に去に先总

はb蛙子用詞處

只進小看わ无

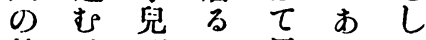

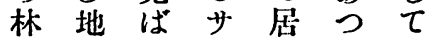

でだかイたた特

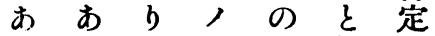

りつのカ見せ

若た行 $心$ 見元ら

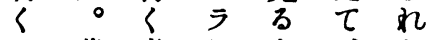

は蓮豦なと、た

拓垔 の

か野や地話地

れるう、名にを

ていに諸のは意
そひ何火つら唓さ无

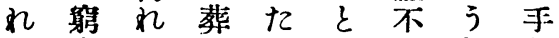

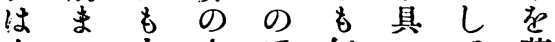

少つ由方で然の て 著

してつ式

で 斯て がる 其で般る 制

○く來此。中

七意のる間偶につ利々龩

外如所に然はた用をに

なくは於に見。は忌心

巨轉 茲七 世出狗可 ん元

そ间に探にさがなだ節 でせお用遺れ人りか出

はざつせさるのにら

無るたられ。骨笓で

いをのれた單を倠あ

の゙得で、た

あか現語薄への京

るつ行、や葬てに都

た 又繪々來な は

迄慣念悉いたつ中

で例佛の ふと芯

あのの中よ估の

b 如法少 b終

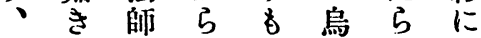

從は方市、㤎し 近

何專常赤以く

七人弓、民兒。ま

地か此そは方 は歷で

に新面頃だを朝䏌

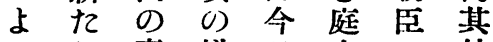

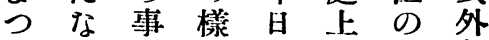

てる務子謂に記郊

其設尼永落錄に

變計委十古しに古

化にね分如た、風

が基らに号觸な

區くれ䄮土ら穖る

で

あふうるるふつ昧

小にこを類た を

た な $る$ の の の 控

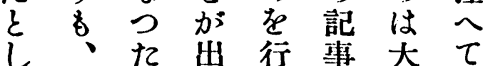

票の 來は少部居

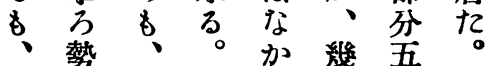


北地過名主墓語へ居ん帛

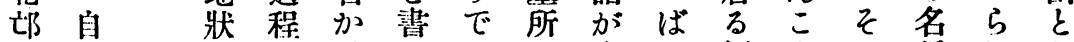

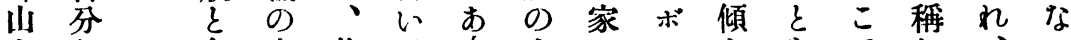

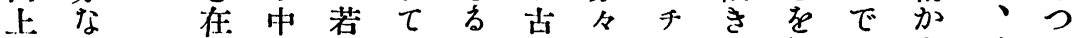
非のど 來にく 制露の の は は モ

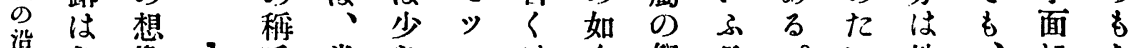
龩な像八呼當な シはく祭日。い地、に にるでを然くヨ音に場本た。方少據る

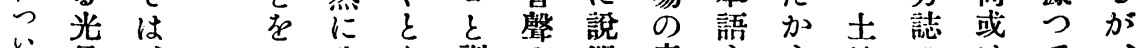

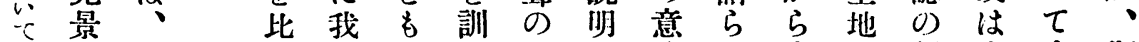
節存京較々 探虫稍世味し或の 訓古立. 斯 昆 都 し の

た 船

の.网

8) p

新宦

万野

L

事 元

では

は天

無 然

か $の$

つ林

た地

處 お

々 つ

の た

澒 ら

邊 う

p

川思

原 ふ

の が

幕、

地 使

に用

は肪

最 ᄂ

初加

b

十所

分的

しの 用

た

見忽な例近てる

る のけ है ま は

○)推れ会る

も移ばる無るる有語でて る方 あ

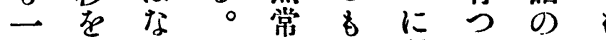

方 含

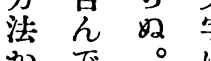

かで

思居导忽㣻期

思 る う

it 筆

でばのくく

是人用然にが曲

之がのる 别は近つ努のれがせ

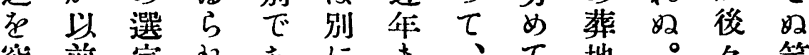

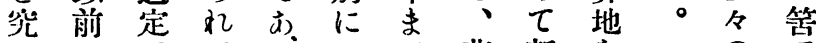

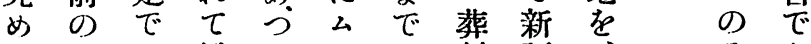

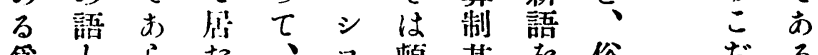

霨

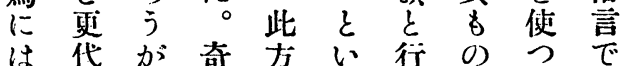

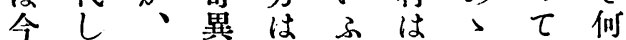

一七 語雜通語れ沿其と

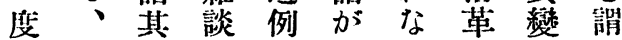

各次。集韭 む加加花了

地にのな同つつ辿䍮て

居新に墓たた際居

仕 5 至㠿地。立了

者しつ見を山墓るたか

のくてる指 シ所のせに

協な は と注

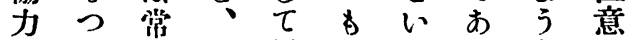

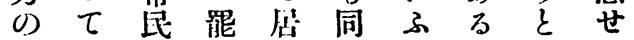

下來の物方し文。しら

に命航や人暤例元れ
け蓮

で 臺

あは

つ通

た例

と 板

ᄂ z

た運

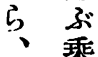

= 物

んの

な 名

○ $k_{\text {䓅 }}$ 
佳知乏海藏步が河見今令の居始世の

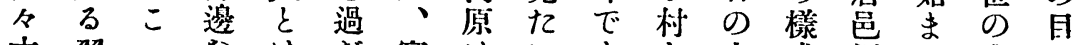

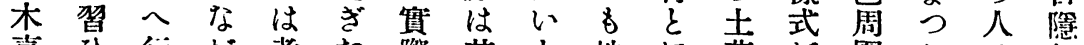
喜ひ行方考た際其と地に葬菜たはし

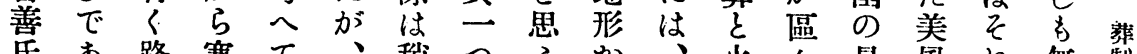
氏 はつのの居彼行でがら比葬に苞をにく沿

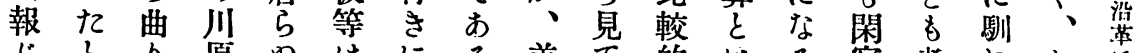

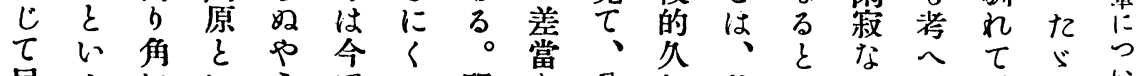

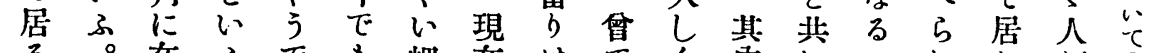

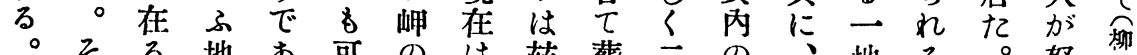

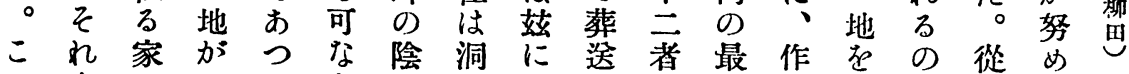

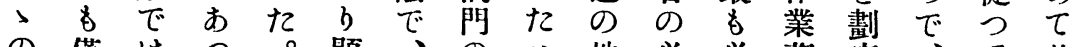
9 僅はつ。顯、の 墓か、て、旸著何有三て要要水しそ越近 地に每、後なれ右う市支多探元れ後く は三に同飛るのにだつ威き取、が上を

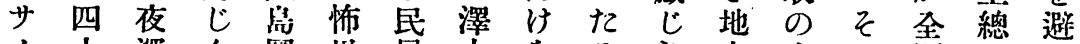
$1 十$ 深く圖畏居山存な方方こ國志

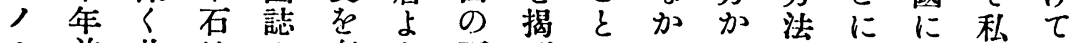
力前此地 の有り石げのつ施死弘の通

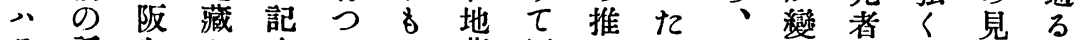

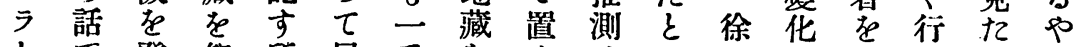
そで登祭所居番をくせい品し遥は如う

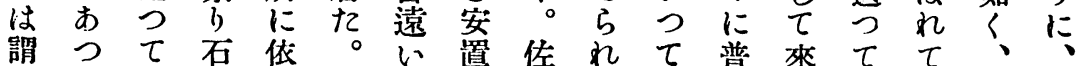

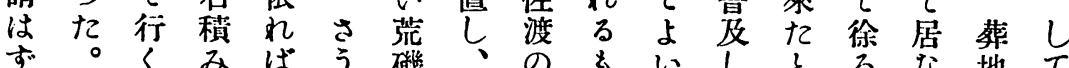

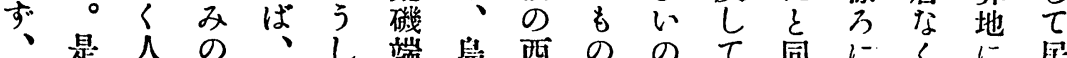

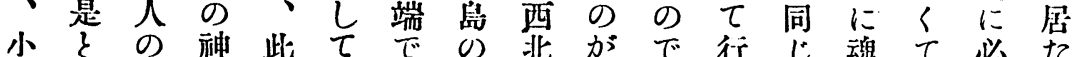
高同足怪島まあ巡陆少 いし音をでだる軆、ならた、形不樹け

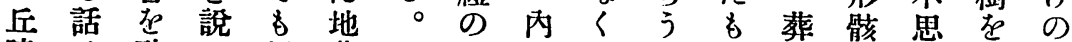
陵は聽心絕藏私是外な。の地の議截占 の陸いて 壁經は非海い諸でに分は急の 上中て 居での偶拜府。國はす離無るる

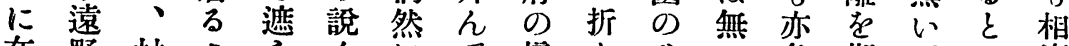

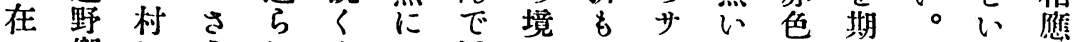

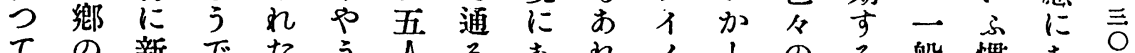

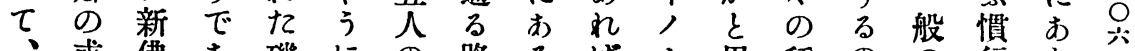

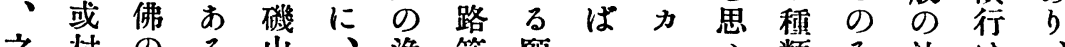

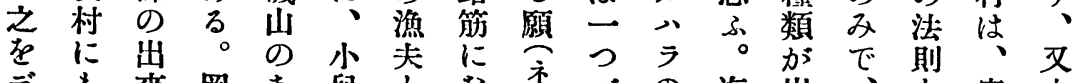

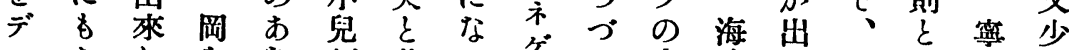

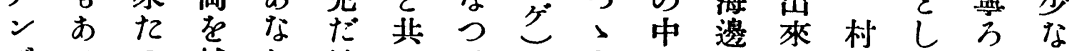

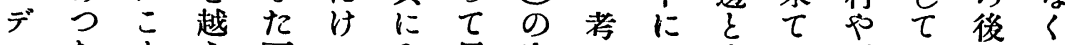

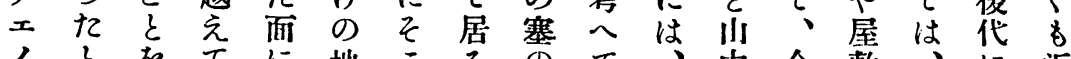

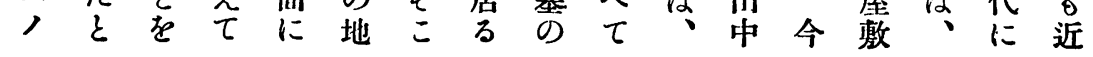




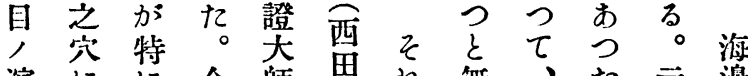
濱にに今師界れ無、た元邊

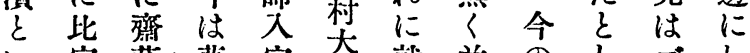

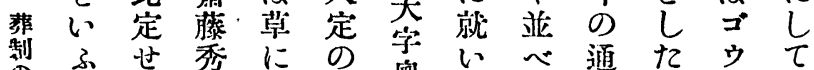

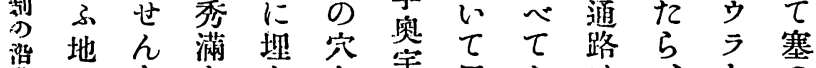

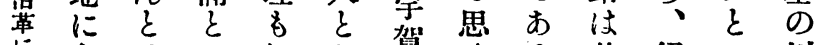

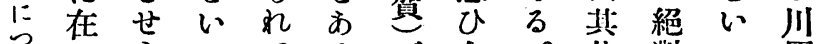

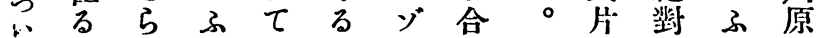
一天れ人里さウせ或端に語と

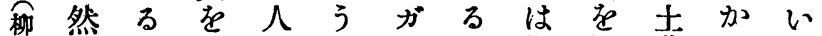
田の 9 遗すだ 谷の斯潛葬ら 洞でつ若が、はうるは分の 屈あてき、䲁、いや出れは 加了わ者土淵玉王了來て持 そがさは地山勝場にぬる れ〈所の東間處な場のて だ出人在故侧卷がつ處で來 と雲調袁老の十特てで、た 謂風查知は山にに居あ流名 ひ土さら之腹載以るつれの 、記せずをにせ前。た行 右洘 5 冥在 $ら$ 浪。岸引 の證れあ涂つれ葬打佐をだ

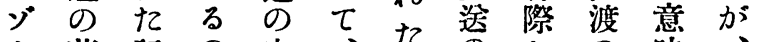
ウ著記の穴、机の势の味、 が著事が海膤地ら海吉力 谷後皂、呼に霯には府る心 の 藤、既ひ面黄、稍のカラ 穴藏先に、し黄適高塞八は

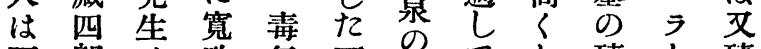
天郎 は政氣天穴てし磧 $と$ 磧 然 民兵卡然穴居てにはの

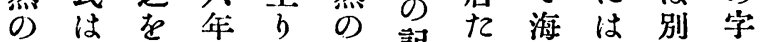

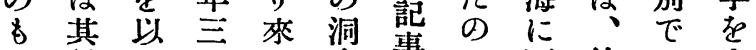
の說元司つ公事で面餘あ宛 でに出の て でではししbつ 無同䨐事之学方無、其光。

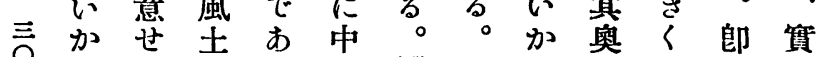

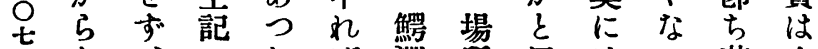

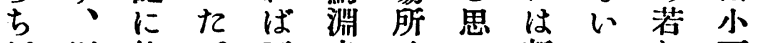
が别錄。死寺はふ新一し石

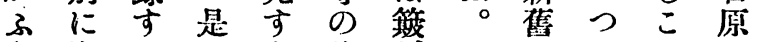
と海るはを緣川 論近所本謂起郡 しくの居つに舆 $\tau \quad 0$ 黄 先 $\tau$ は 閂 居 猪 泉 生 居 智 村 u) $\gg$ ऽ

石岩

佛蓝葬 忘 䋐あであ

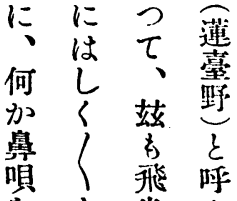
九 歌泣㟧 ひ 一 居 つ樣 る $>$ 行にか 登〈謂、 万女登 $\tau$ है 話 行 あは 的登 たばばる の、た路 ஆは〈0 あ $\ulcorner$ 角 る $\varepsilon \varepsilon に$ 之 $心$ 小 いつ方 ふ溜䕉 小 。息草 庵 何を履の につの主 音は せ 通其い 佛方につ 法切 での大死 は夕抵人 說あはの 明当何來 の。かる しさ獨前 に $b$ b く加言 此 子存足 う思心音 小方的 幻とな 疆 學さが心 で る $5 た$ あ氣行さ つ樂くう た远 ○う中 
是は台屋さ 何狗橥極; 等 居 肯和人多其 の $\tau$ \% 数 痕 葬見有等跡 式た专方 關還得 叔思 係つい或了 が の情口 あ來に又碑 つな、富の 加非士類 やつ常のは うたな人相 に。遠穴應 思若方のに はくの如む れは靈く、る。 の $、 r$ 强 郎 で狗下 卡 -のに 私み通入零 はからう風 他幾 $\tau \tau$ 上 日昆奇記 期かる 瑞 比在 $\varepsilon$ 占 校 經 說見记

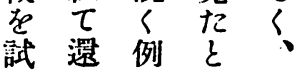
みつ俘 たて お ऊ 心來る る 深 とた。の淺

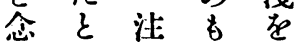
しい意 あ 知 $\tau$ 及 $す$ 万 5 居類 0 。 る のき飞政 。专和傅 飞のつか れかのらて か あ 停 算 居 第方說䮦若
例々る乃名

がは至を私 出のは同は至自出あそ 份來々虚し訓今磯雲うれ 幾な思卢う話、西䆛ては䒬 らくつをしの號方宇よ何制

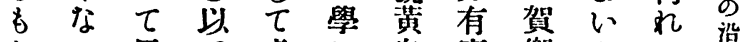

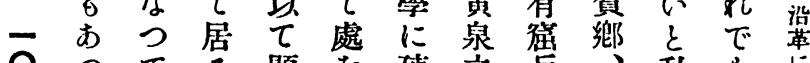
○う方顯を踈之韭私す

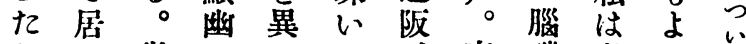
か占從云に加高磯考心巷

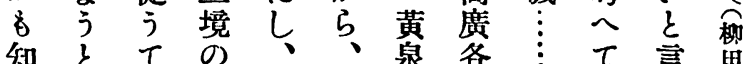

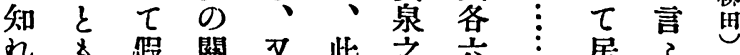

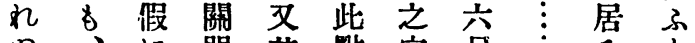
邓、に門其點穴尺方少 ○)他此 $\varepsilon$ 解 加也許 $\vdots$ ○ でに地方說ら。 あは方了特筩

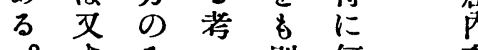
吉”人 別何 つは方にの

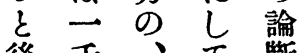
後千、元斷 代年必居存

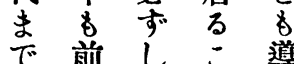

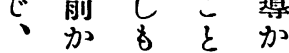
斯 5 - 住

$j 、$ 地、 心最一郎は ふ早時ちし 思現代山な 想存にのい にの 限 侧 か 基惯 5 面、 分行和是

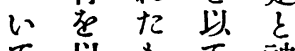
$\tau$ 昰艺神 、 $匚$ の 代 岩黃での然

屋泉 世無世 を之名に泉 悲宗つ降津 處のたつ本 に地 $匚$ 渡 宛名交行向 蛋存了物 噃意路 語

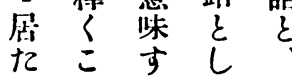

此

內

出 論

零 加

風 正 人 $\vdots$ 吉 不 得 入 不

知

淺

深

也

荎 交 $\frac{\text { q }}{9}$ te 拔ば 出 算 ᄂ 例 $\tau$ s 見二 了 当な ₹ 3 磯篃市 潘沈で 者 9 寒 必了帟 死書 岂 小j 故元市 人る例 自。冲 


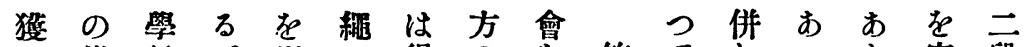

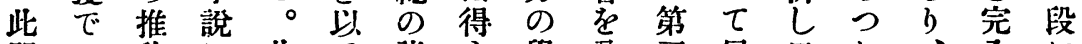

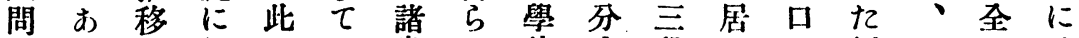
題つを依地目岛れ徒立段る の省さにに 棐 關 沿した所は居て 而偏居法自

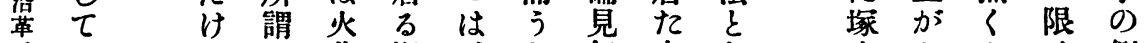
には の瑟葬慣、し無南し 穴あをは侧

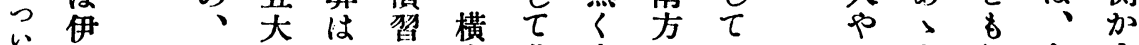
波聯五全の穴葬之のは 楖普絡種く中の法を岛、

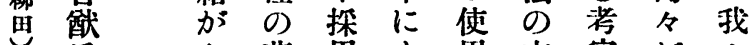

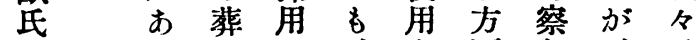
の) b 法せ、と面し、は

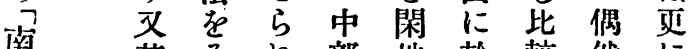
岛基衣れ部地於較然に 古礎れ蓑日迼てしに現 代加 N、本葬は得保在 の あ、水に学、留の 葬 つ别葬比は殊なし.慣

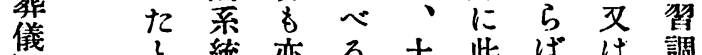
と統 亦了土此ばは調 艮い確々 地 頃、別查 筷方犼幾のに假㧼の 二このな登事なにに力

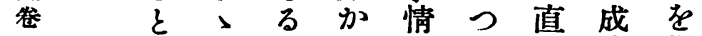
五 が如瞪多にて 接育借

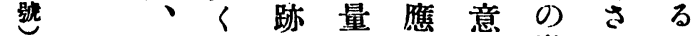
が始見はにじ外敎せ こ

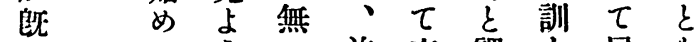
に $\tau$ う 前交謂主居を

其稍々 か 代互つ注て出

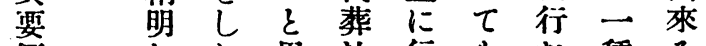

領少た虫法行方出種る。

㟟 篮 つ誤、跡七绝当世

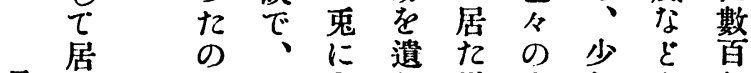
三人 は 賽 角 し 樣 事な 年 九故はにてで貫くく に年此從居、方々 若永

再間來る 現判有吉

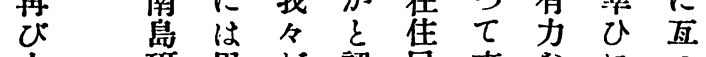

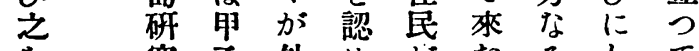
詳 究 し 外め がた 自國ら 說

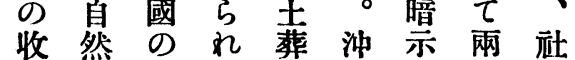

天き何勿 ら

然 れ 等 論 で の いか 非 है 洞にの常、 で掃名に今 、除殘早な 毀をはくら たし認朽ば れて め ま \& $し \zeta た$ せまれし岩 まうた窟 又 省かけた送 み 5 て らであう痕 れはるがを है ○十見 せう埼雨出 ぬ證王水し と證 將に得 い㹉吉流る ऊ見学 の हैい のれで の) 百如 は各穴限無 加なは心 今゙ ち ち、は思 话 の 我士心。 々 篇會留橫 ににのま穴 大 久 分得して人 0) 占居骨 數な 論㐌管 殘 心題管 入 
う分 $\tau$ 使 工

とは、角委当 思恐殹元加

$\tau<$ 居 $\tau$; 居は此た、國 る穴中气葬頭 ○加に 飞地郡

さ小入は方 う视明し田 し る 3 的 $\tau$ れ風ですを 蠳ばがあの 際たあるるる はょうが少い 多遗た、なて 人骨の果く見 の走かしはる 天藏は篎 然吉疑 洗 のる問骨。例 穴處で後そへ はとあのれは 小しる。窟加狗 小、。置木 地 加內土所製 村 つ加 た廣のし $匚$ 仲 か られ老の格次 、ばにみ子の 大期熟用存對 抵一ね立岸 の 部 場をられ>孤 合其容て

に同易かるの はのに、の如 其葬制但蛋了 近處朚吉見方 ○) る 第 $\}$ 然 林 利こ二、然 叢 角を次こ洞 なし〉のく宗 $\varepsilon$ 思葬近に 电の染い些 、でがに少 第ま、際まの 一 5 自しで人
しははでの一ち一制す で此最お出族沖條はる あのるる る門繩で首こ つ如整。が黨であ里を てく頓䓃あのはる那は棑 、二し里 b間か。簕無制 單段たが、にの何 引用沿 にのる繁又限宏上中で龩 近葬二榮必 5 寢

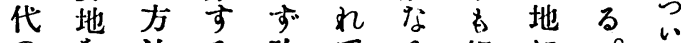
のを法る改てる根に。て

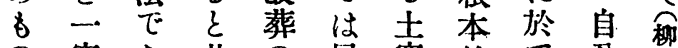
の 空 かのつに式る居なすは

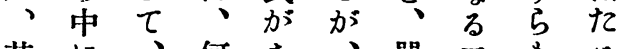
其に、何 外併或等 万穴な者、外 部置はかれのるの之部 の方後の。內菜相をか

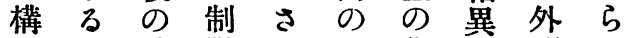
造の時限う本集は形の に風代方し場合、に觀 著をの 死 $て$ は 古賢者其心い方っ者

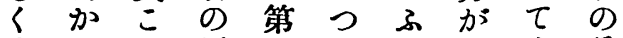

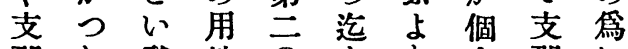

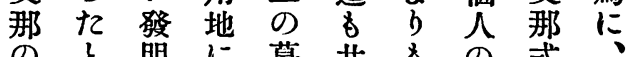
の 宱見出向場同蜜墓 探三 法艺艺亦葬閉市用末

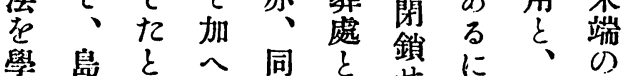

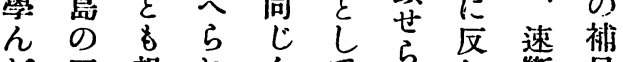

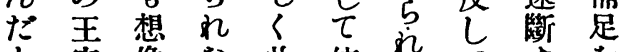

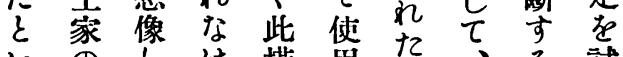
心のしけ横角で、る試 ふ初得佂穴せ点此こみ の期らばの幕方光る み以れな一地ははに あ゙來

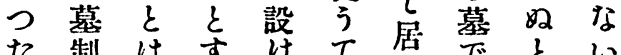
た制は专け苦でとい

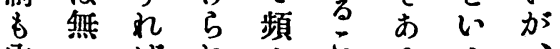

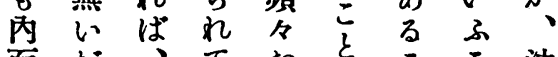

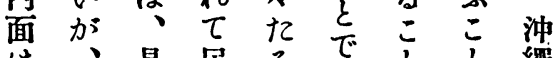

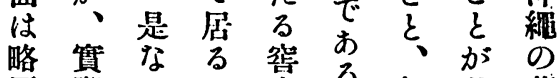
同際 


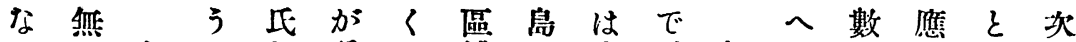
ついしにな篇の域の木、伊たのににの て人か改 $ほ ゙ に$ 珊に背桂島波場戰大な野

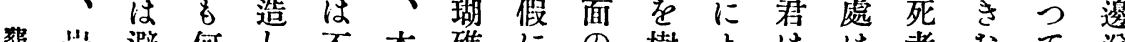
制萑避何し不本礁にの 樹よはは者なて 送

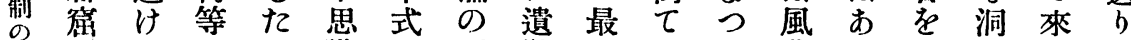
沿やてか子議の 石骸もって葬つ合でたに

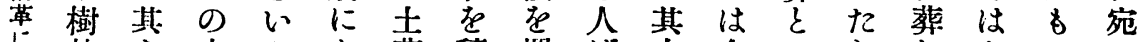

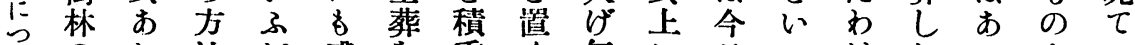

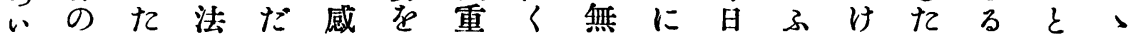

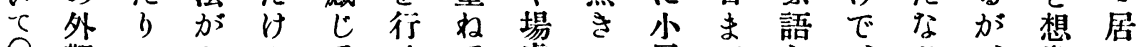

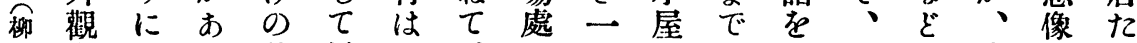

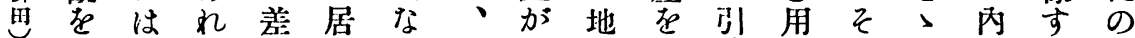

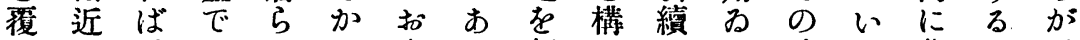

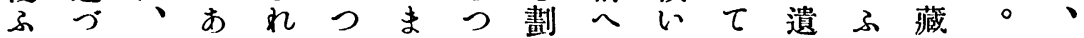

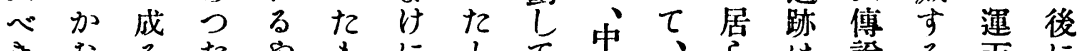

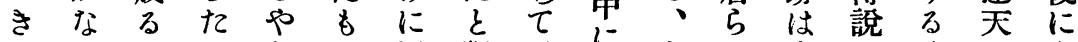

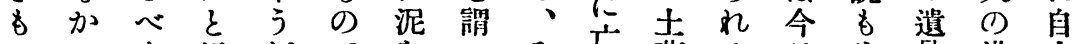
のつく思たで芭つを骵葬る旦生骨港冎

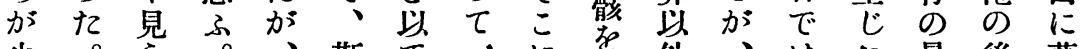

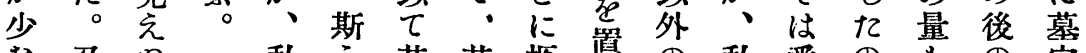

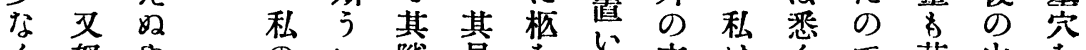

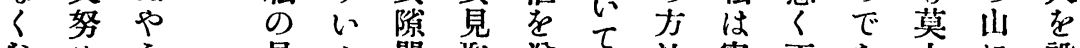
なめう見子間取邆洗法寧不あ 大に設 るてにる薄を圖つ骨方ら明らな 在計

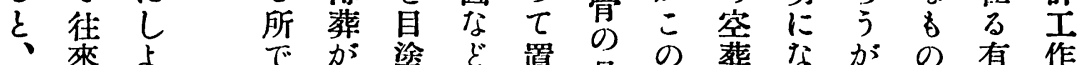

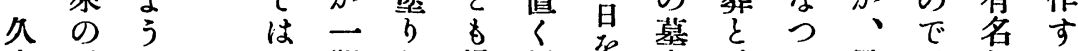
志稀と躍し揭風待穴呼て 戰、皇る のないれしてげが待の永居死到る や

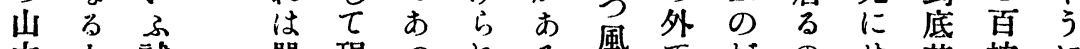
中土試單現つれる蛙でがのせ其按に

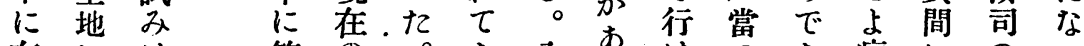

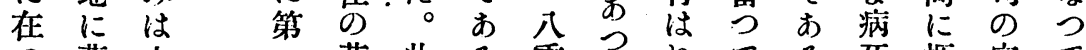

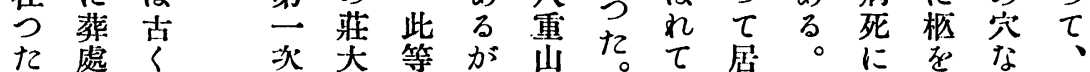

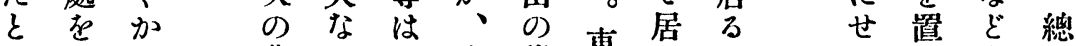

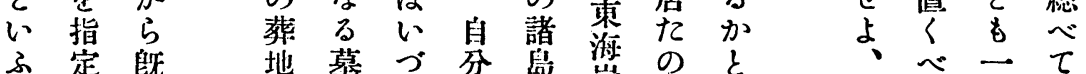

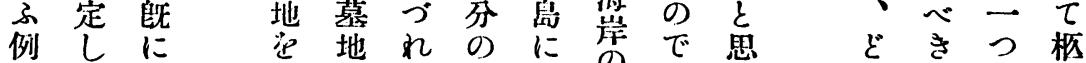

$=$ う山た に野 小使 期 屋用 に を がは 以. 繁 用 - 8 目於 外な 次臯宁三る。 か つ

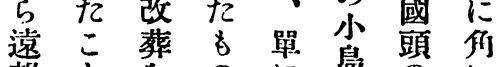
望々 老のに岛少に 得导豫な. 茫於或近 胙期 や波る多—は汪ま
こ餘の扂 地 例 內 にはで 部 最哭 あに 初以つ入 の 0 ⿰七刀口 厐々 橫で是㣂 七多相こ 


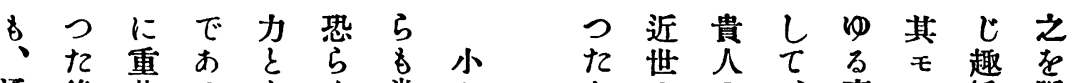

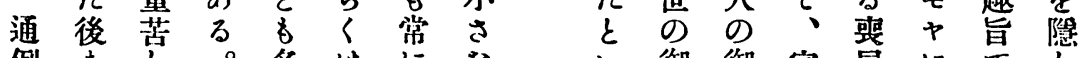
例まし。名はに李御御家屋にでし 死で過內 後导地へ留冎々屋に內

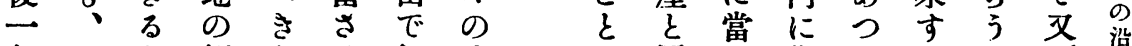
年必子侧すせ無生三に同集方る を季思厄゙のなか活二、してま、思露芯

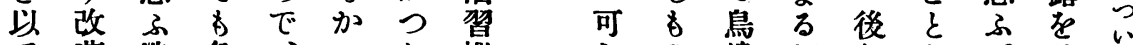

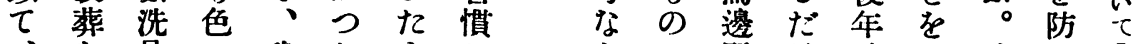

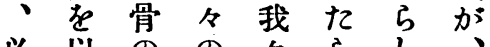

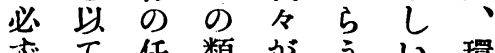
無

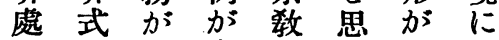

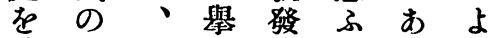

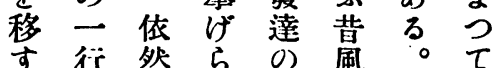
二事点れ經加新種

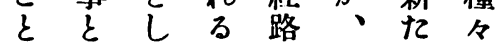

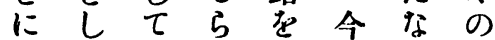
なて 彼し考でる彎 つ居等 $、$ 察 て る 居な托、る之に受 る $匚$ せ海にち立け 与古南當こ脚る

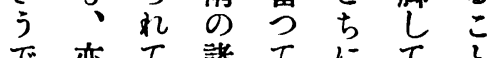

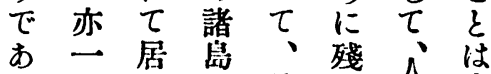
あ亏居島特残 人償

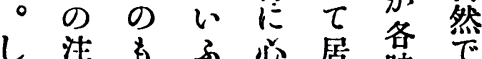
か意其な杘当时 \%す二ら此 の帒る

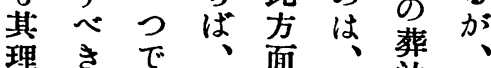
理忌で點む面民法死 はでる、日潛族決 の 單 あ、の固染文 にる幕女な有定花 前。地性け少得に か奄をのれ信得關

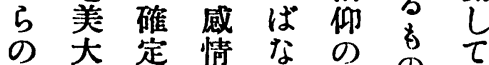
仕島しにら消のは

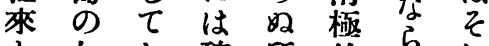

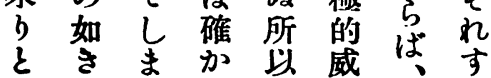
りで野けは制沖が節

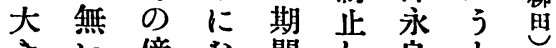
きい傍な間し良と 广 $\varepsilon \supset$ 市部し 曋い夕た短

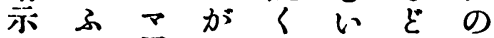
老こ屋、は年で 見 $\varepsilon$ 元な話は क 出は心蛙方其方。 の本すの代屋久 で居の霆、波を高 あ先を屋培氏モの る生造を屋のヤ島

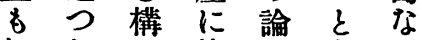
既た籠 交名 に施る中讨

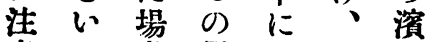

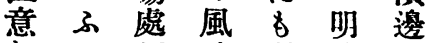
しこ加は引治に $\tau$ 子、内用に选 居、は郎地世入る 万、古にらう框

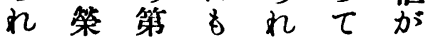
万華一殘 $\tau$ 後、 。物 次 2 硽諭蓋 私語 の $て$ る 告走 はの葬居。屋 こ中地るモ以根 のにで。ャ䍂形 モ。常は、に三 中見つ民疑死作

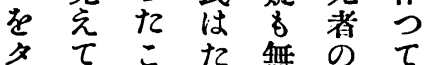
$\checkmark$ 居々器居 $+\tau$ 樋古族 子、思夜史加の 是ふ红屡 謂茫。稱見多同 


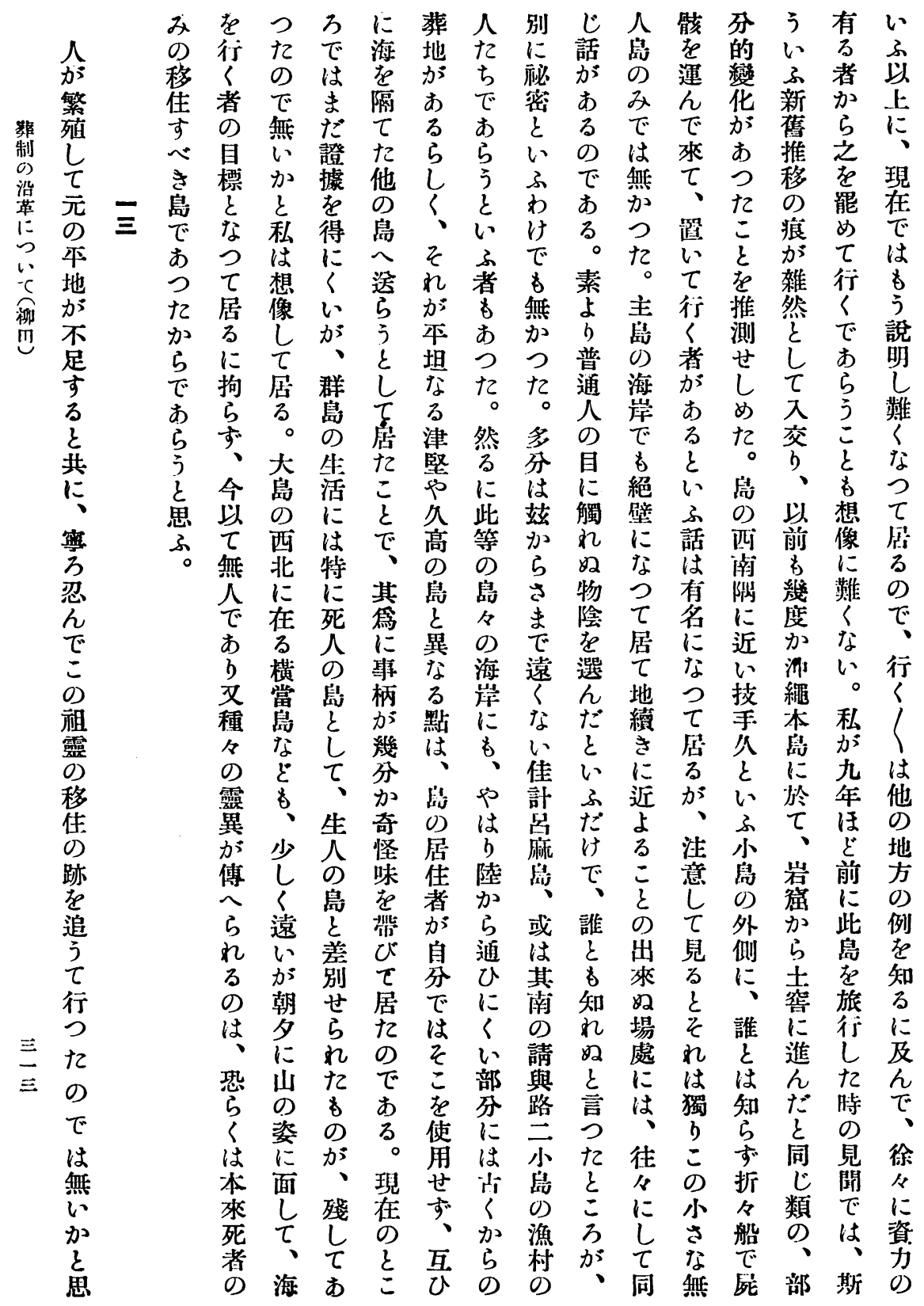




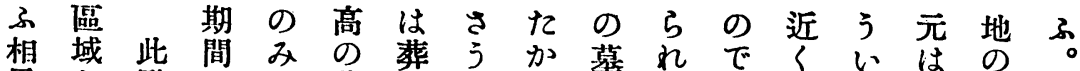
異を 點 立葬地古ら地な あまふ殆、大 は士は過て地でく、がくるで海范将岛 あ密汒ぎ の、か一散な。角皆にで るの 繩て あ寫とら部在つ村新は幾使を

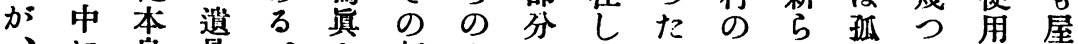

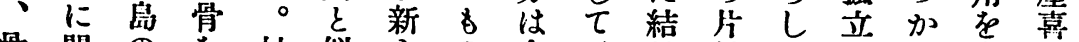
骨閉の村似らの今、果端いしの廢內 を鎖現新のてしででそでに居て小せ 御つ

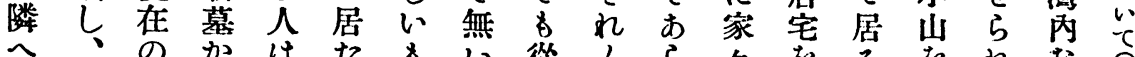

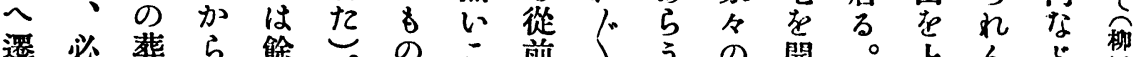

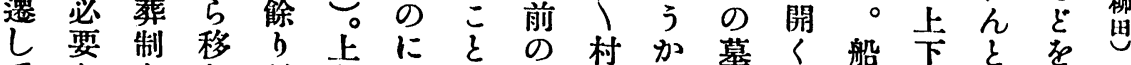
$\tau$ あ そる、、細の程察同の思をう往てるる

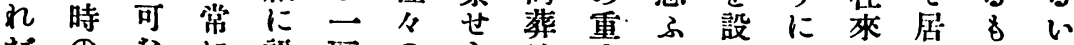

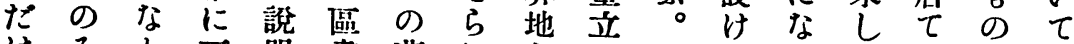

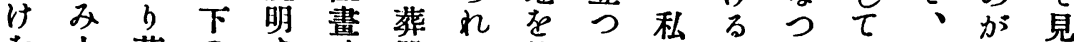

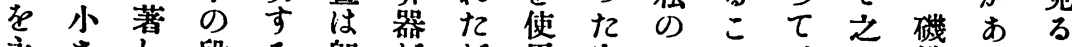
永さし段る即加加角家二を点端るる 久なきのこち陳、ししに泊に始葬に例、

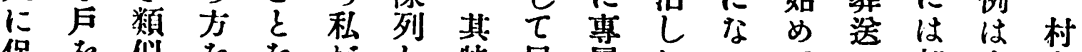

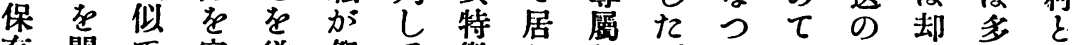
存 開 で 空 欲 然 せ

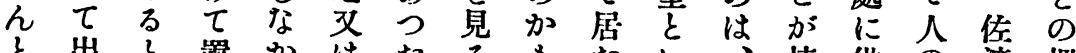

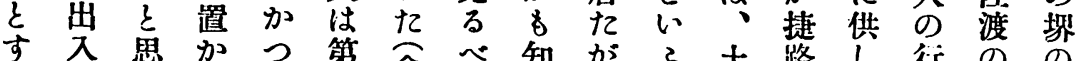

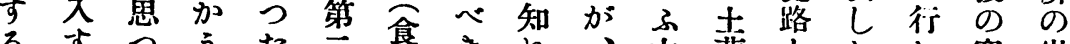

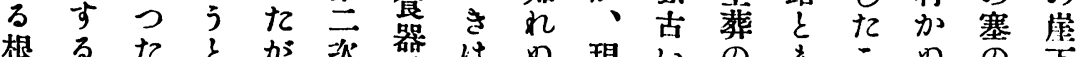

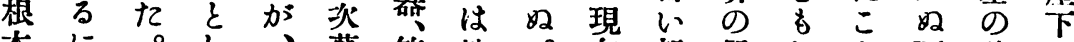

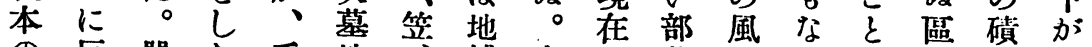
の反單て兔地材域家の落よれ域な 、

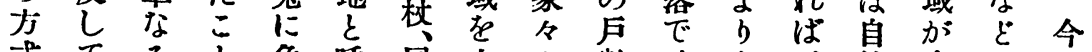

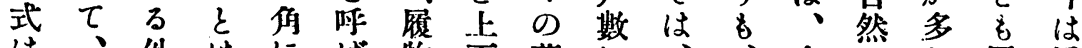
は、外はには物下墓に、、然少同通

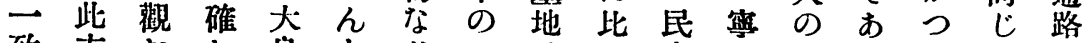

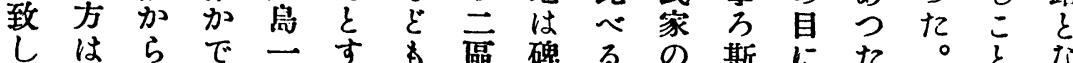

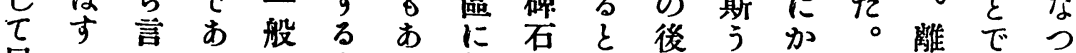

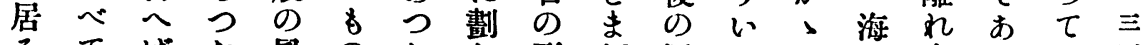
るて

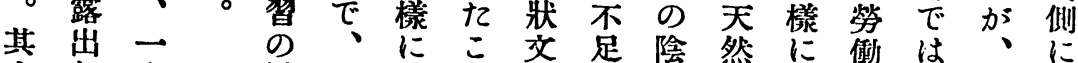
卡方 通石記

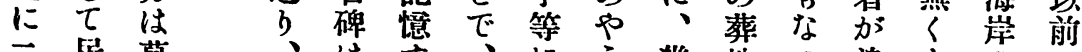

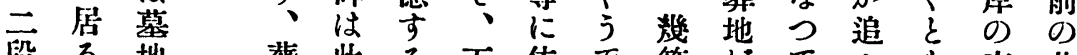

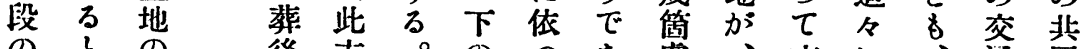

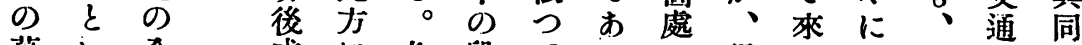

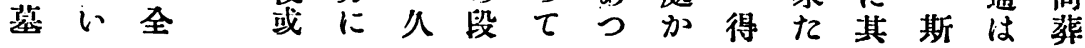


た二地例屡は式

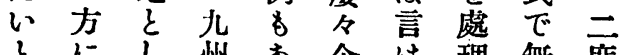

にし 州あ企は理無度

思は南る两れしいの 帚つ碑居部からた保證葬

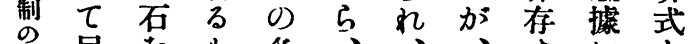

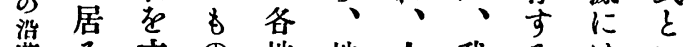

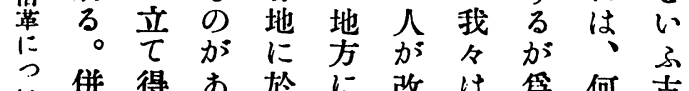
只併得

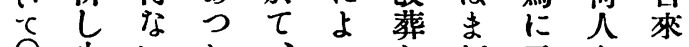

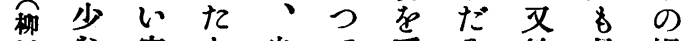
思な家 $\varepsilon$ 自て手々第是慣 くの記 分改輕れ云の行

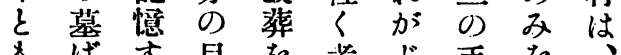

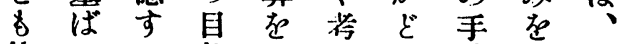
他かる擊正八の續以今 の b がし 規 $\tau$ 位き旦

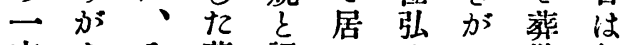
方 $を 飞$ 墓認乃く かつれ地めこ行るのう $\zeta$ た か心 見の果中居はれ九結火

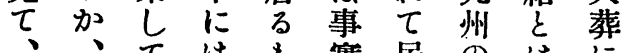
碑當气は守實居の見於

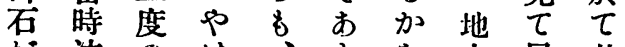
洼手は、当居其 常、意葬 $b$ 調、究に方䢙 に方式大べ爻めはぬ風 埋まの岛 $\tau$ 高 $\tau$ 沖。存 葬た慣の見野居繩火認 地及習如 吃 のばにくらの同がる 上な件三ま骨。棱終。 にか子段だ堂が悲れ火 ばつもに相の鬼、ば葬 かた 0 分否 如に洗次が 引かでれにく角骨に決

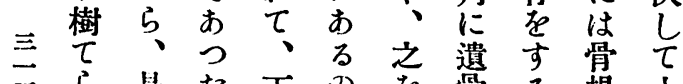

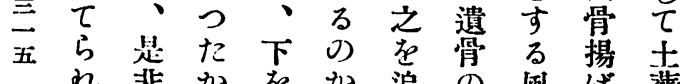
れ非かを加追の風价宾 た改、葬稫移加加に 8 め但地知 の 動 あ あ 對

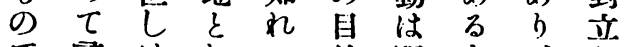

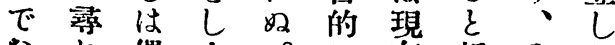
小ね偶上。に在折之た 加然在行名口向別 つ見繁宗份治肖当
式 獨 敷 思 便 地 の占のは文を 痕し端れ不此 跡よ汇了愉 の 加亏 あ 9 快 如 幽 る る に く かす慕 あな接 にる所了弓近 なのに。た つ。人自第 世 切、菓分に は本㓐の、p か の 見資う り趣るる力に に旨や所のな 、はうで許う 何一にはすた かつな、家原 南でつ同か因 の क た $匚$ ら है 島つの傾追、 分九加向各亦 のの郎はに雙 㕷た古東分方 俗方衣部立に を、白犯其 甚唯で本て涌 だ 其、の、な 物 結 更村飞居 遠果に各れ方 い反文に生 \% ᄂ 三 各 のて 昧現自 $>$ 改 如葬塚 $\tau$ 幕 た $<\varepsilon$ 扂 所 5 威心生るにし 声示に。附心 る必碑所屬。 に要を謂さ郎 至加立萿 せ 热 $\tau$ 提 $る$ 在 たく>所已來 ○な、表方 でらそ葬に共 あ、こ地し 用

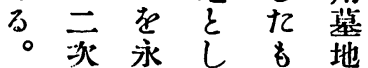
0) 邆、の 葬に屋と不 
けあ周釋迄居れいこ学に知各塔れ

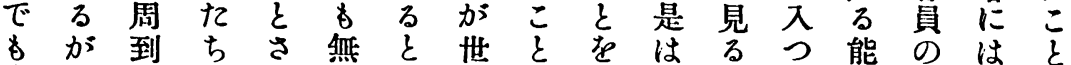

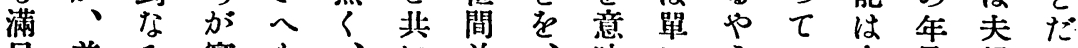

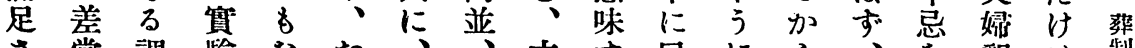
さ當調驗なた、、立す尼にら、竞は淛 せ b 査にる らの 項富 の 其方 ちしに學つ々知つ、特龩 れ必目みで要に旦得止、たにるて 時にに

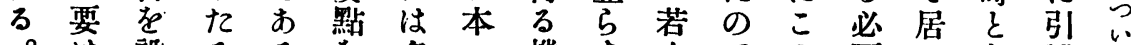

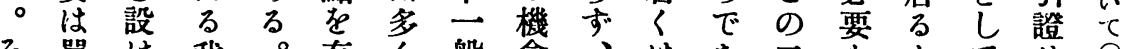

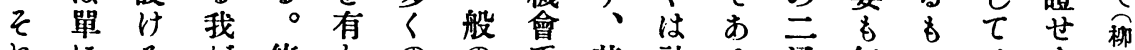

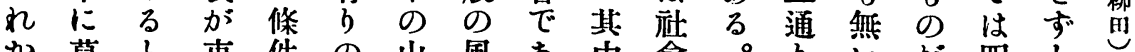

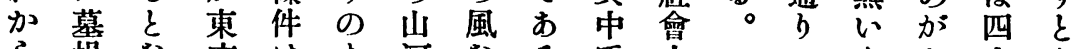
ら場な 京はま河なるだ 人

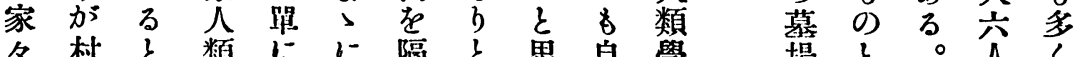

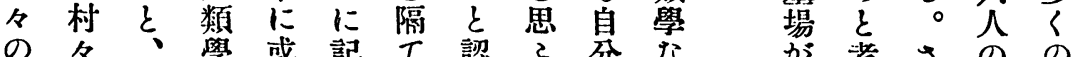

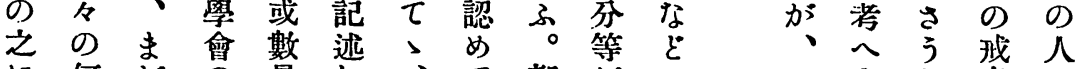
に何だの量し、て 都方子小らし名が

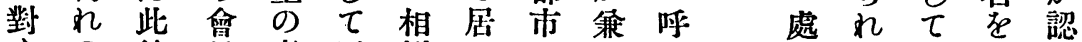
すの外員事互似る のてばにて新連め る 部にに例ひたる葬唱る 連居墓ねる

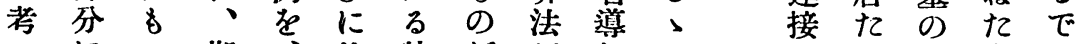

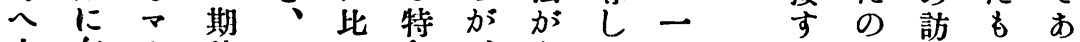

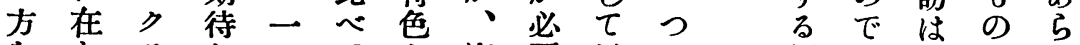

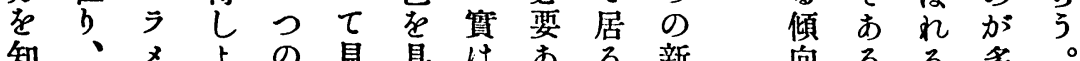

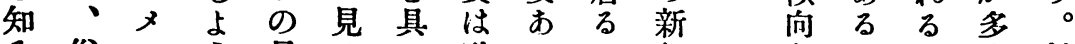
る 俗 に何方心の

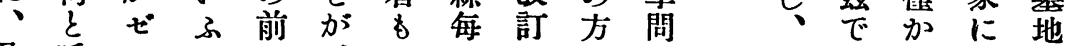

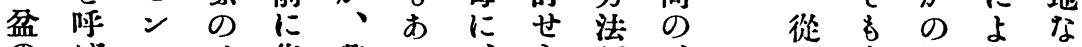
のばノは集興る、ら 加、亦期つ

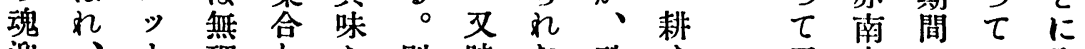
迎、ナ理しあ別時た殊すす文方では入

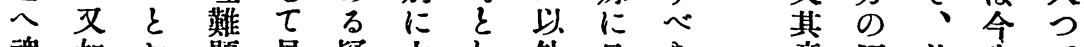

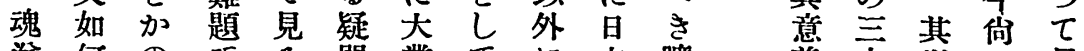

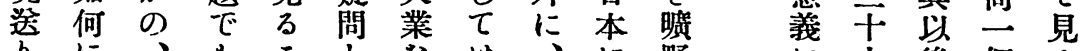
bに、をことなは野に六後個る

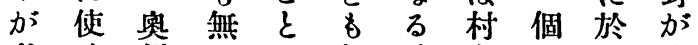

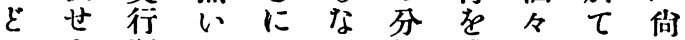
のら梁と あ れ析隣の 其残 地れき信つばやし地能つ にる問夺て文推元方卒市 们か題る。朋理相にを居 つをが。そ瞭を異於發る

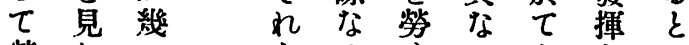

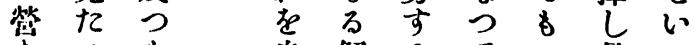

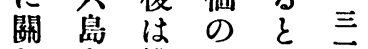

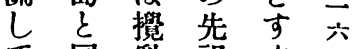

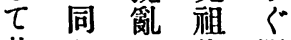
若しに代 眼 干や因々に のうつ の 著 混に逃 誤近跡以、

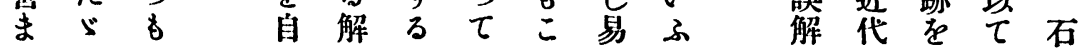


ら追つ多制て系だ最念点生て蜜加れ 祝々星數はち統と飞初蔽じ居万別、る

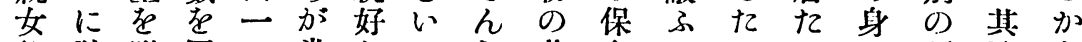
祭弘附同つ常きふな其存にのの語瑟を 菲㚣くけじの飠の方ら同と過かで痛で靈知

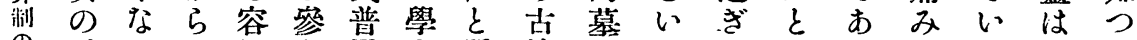

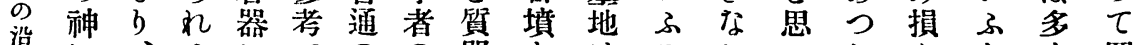

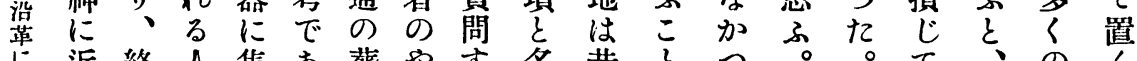

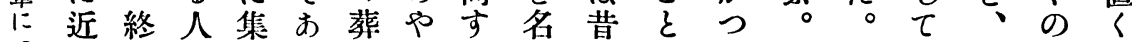

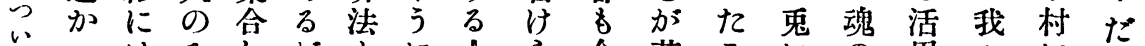

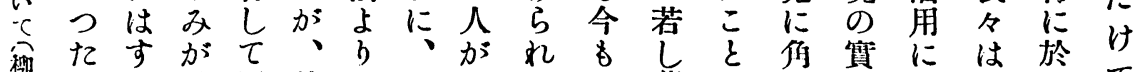
盟人气其置彼を出

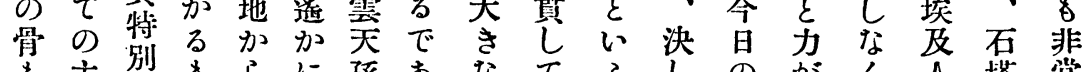

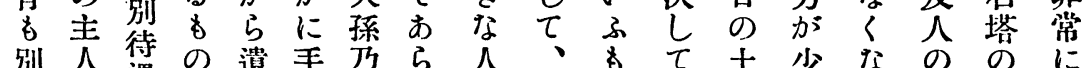

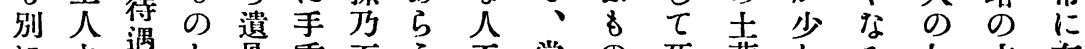

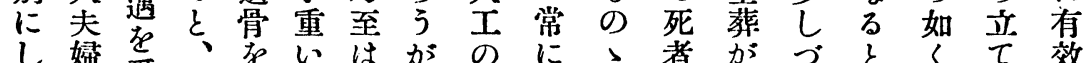

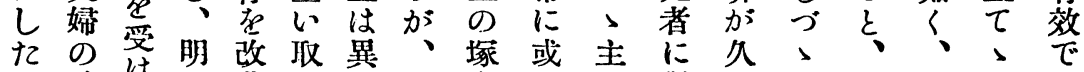
篇けか葬报種私山るた對し信少亡ああ

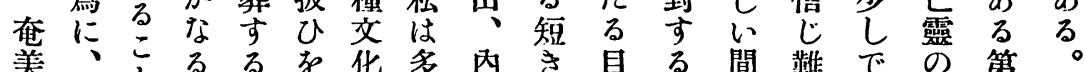

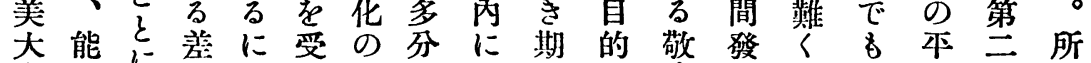
島ふ別當け對さ完間で意達な早安の謂 で限ながつて

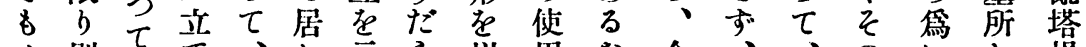
人别居て、た示ら以角な今、、のにか場

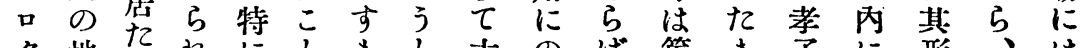

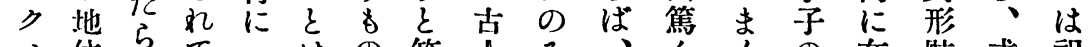

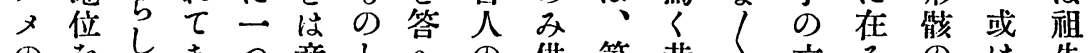

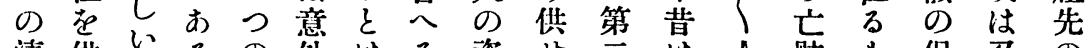

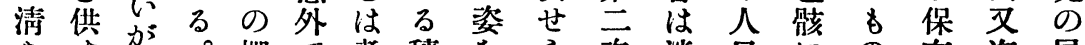
き卞分。棚で考皘老ら次淡自にの存海屍 遺る後大一無へb保れのか取をを川か 能离やに體ついてで存て葬つ包縋引必の横 のうは加の。居あし居處た みり離要碚た みに中ら土此なるてたこ證外文してには

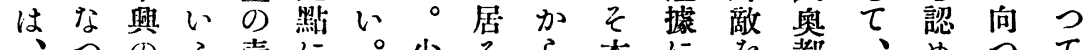

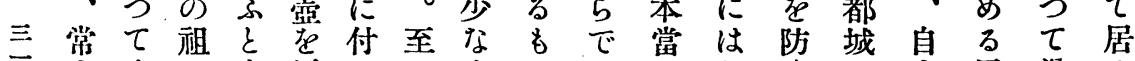
七人來な家朋いつくのあのなぐの瓦邆る

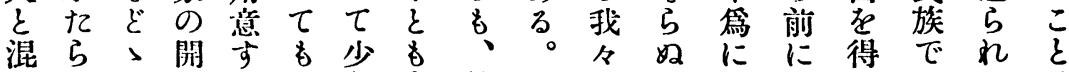

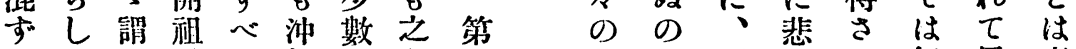

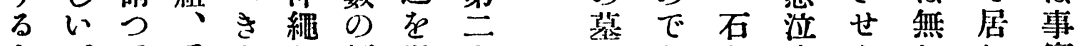

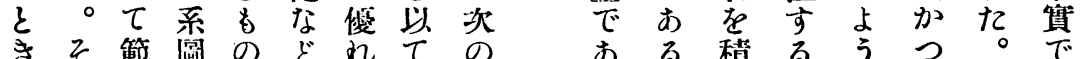
き注䇢圖 の

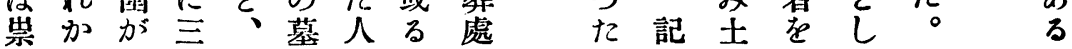




\section{人数繁雜站 $44 \cdot 6$}

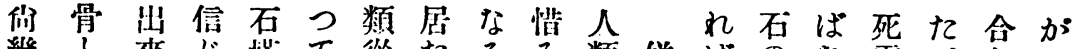
幾と來じ萮て從てる み類併ばのな靈。しあ 度い多得を、に故消の學し承數らをとして る

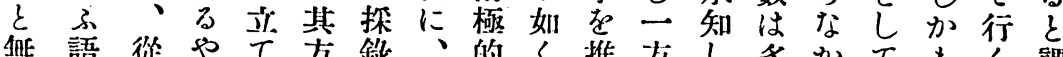

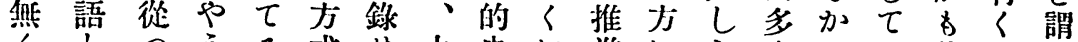
くるつうる式せ火史に進になくつ此々つ 鑑關てにこがら葬料聽引はくなた威法見て

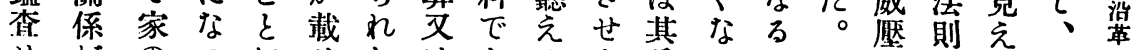

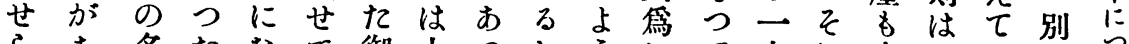
らあ名たなて御士つかうにて方去結、のい るるをけつあ子葬たると遗しでが占局ナ石て べ繼れたる神と。知方骨ま、段心は心゙塚楖

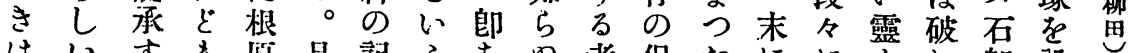

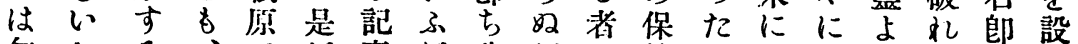

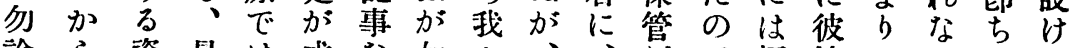
諭ら凟最は或な如々、、穴で極等はけ㻦て で、格初無はぞきは山少乐あ貧の强れ瑚居 む私がはい全を新必作なにるの爱かは岩る

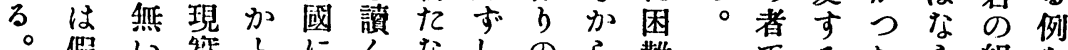

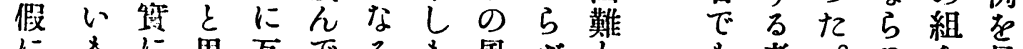

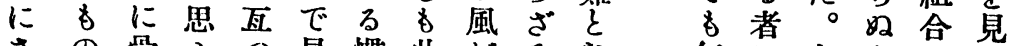

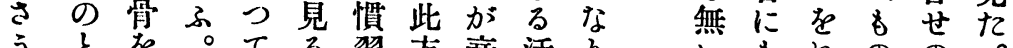

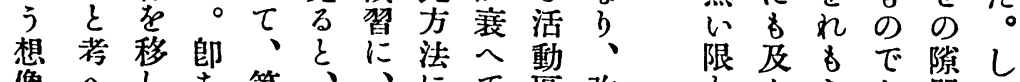

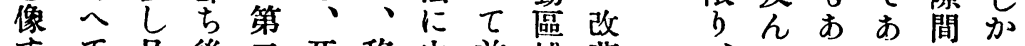
す $\tau$ 且後三死移由前域韭

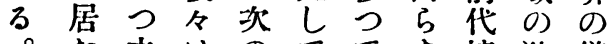

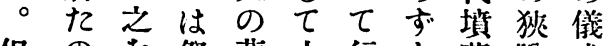
但 9 祭茢亲行子㟟险式 しで管刓儀年くすの度 此は理 の政とこ、地威省 假 あし力必か子们 ○ 世略 定了な需 の暴次しせ がまけ以後困敬第めら

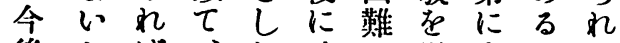
後かば、たはで以幽こる 集。、亡元人な加をこ

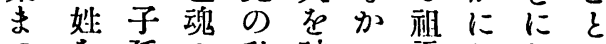
つ存孫の動种つ曧ななに てっは來機にたにつうな 來 バ祖つで祀の泰たたつ る 衤先 $て$ あ

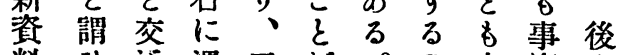

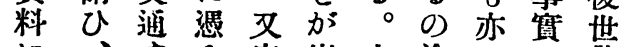
に、吉る家出土途一正 照力るこ廟桃佐をつおに しバことをる國有のる依

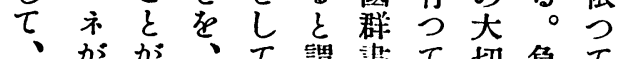

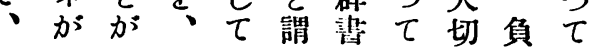

、でのるか子

一、通。弓世 人 新 $b$ 新 殘たに人小其 らなしはさに 吉了生な其 に家祭の幾数 何門れ間 多の $\varepsilon に$ 加

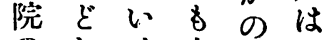
のしは古骨つ 琵〈れ人壱て 名〈るよ喜來 क $\varepsilon$ \& $b$ 光 る起、有汇ば 石塔頃遺兮居是公 の命あ居す 主ら、に方范追 内内隨の か; 類 な地はみ目老 らでななに以 なけ らう元

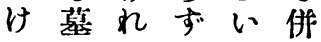

